\title{
Татяна Александрова
}

Институт за български език „Професор Любомир Андрейчин“

Българска академия на науките

\section{Руска Станчева}

Институт за български език „Професор Любомир Андрейчин“

Българска академия на науките

\section{Някои формообразувателни типове при глаголи от първо спрежение в българския книжовен език}

В научните описания на българския език неведнъж е изтъквано, че в сравнение с останалите славянски езици българският глагол е развил най-богатата система от форми, изразяващи най-голям набор от граматични значения (вж. напр. ГСБКЕ, 1983, с. 209; Куцаров, 2007, с. 105; Ницолова, 2008, с. 224). Разнообразието на формоизменителните модели мотивира редица изследователи да разработят различни класификации на глаголите по формални

This work was supported by the Bulgarian Ministry of Education and Science.

Authors' contribution: both authors participated equally in the concept of the study and drafting the manuscript.

Competing interests: no competing interests have been declared.

Publisher: Institute of Slavic Studies PAS \& The Slavic Foundation.

This is an Open Access article distributed under the terms of the Creative Commons Attribution 3.0 PL License (creativecommons.org/licenses/by/3.0/pl/), which permits redistribution, commercial and non-commercial, provided that the article is properly cited. () The Author(s) 2018. 
критерии. Класификациите винаги са исторически обусловени - отнасят се за определен етап от развитието на езика ни. Най-разпространени са класификациите според съотношението между сегашната и аористната основа на глаголите (деление по спрежения и разреди) (вж. по-подробно Пашов, 1966, с. 5-26), но са налице и няколко по-обхватни класификации, при които се отчитат и на други делитбени признаци (вж. напр. Кръстев, 1997; Малджиева, 2009; Попов, Симов \& Видинска, 1998; Томова \& Карастанева, 1984).

Богатството от грамеми и техните стойности има своите исторически обяснения. Макар че за целите на това изследване, което е изцяло синхронно, няма да навлизаме в полето на диахронията, ще отбележим, че голяма част от формалните особености в парадигмата на глагола са резултат от диахронни промени, свързани с преструктурирането на петте старобългарски спрежения. Резултатите от тези промени всъщност добиват статут на класификационни признаци при отделянето на типове и се отчитат с различна степен на подробност и взаимосвързаност във всяка една класификация. Според научната парадигма, в която е изпълнена класификацията, както и според целите на граматичното описание диахронно обусловените класификационни признаци (без да се експлицират като такива) могат да бъдат по-подробно или по-бегло застъпени.

Представянето на формообразувателните типове при глаголите в настоящата работа е изцяло формално, семантичният компонент е изключен. Това позволява да се обединяват единици глаголна лексика, които имат тъждествена формална структура, и същевременно да се отделят формално различните единици, като по този начин всяка от тях се свързва в мрежа от противопоставяния с други единици, което определя и нейното място в системата (вж. Плунгян, 1998, с. 329). Така морфологията на българския глагол престава да изглежда като сбор от регулярни и нерегулярни форми и в нея могат да се откроят общите принципи на морфемна организация, което е необходимо за изработването на съвременна формална класификация.

Моделът на представяне на формообразувателните типове цели да обхване цялата глаголна лексика. Той обединява и поглъща различни направени до този момент лексико-граматични класификации на глаголите - лични и безлични, преходни и непреходни, свършени и несвършени, както и обособените формални класове глаголи от първо, второ и трето спрежение и по разреди (вж. за тези класификаци у Куцаров, 2007, с. 108-113), като позво- 
лява да се обособят непресичащи се множества, всяко от които съдържа елементи, тъждествени по определен набор от формални признаци.

В тази работа ще бъдат представени някои формообразувателни типове при глаголи от първо спрежение в днешния български книжовен език. Обособяването е направено във връзка с работата по проекта „Нормативна граматика на българския език“ (http://ibl.bas.bg/normativna-gramatika-na-savremenniya-balgarski-ezik/). To е основано на принципите на изследване на формалните класове при глаголните лексеми (вж. Станчева, 2018) и си поставя за цел системното описание на инвентара от форми на глаголните лексеми, функциониращи в съвременния български книжовен език.

Представените по-долу формообразувателни типове са обособени въз основа на класификация, която отчита комбинаториката на стойностите на граматичните морфеми в набора от форми на глаголната лексема. Както вече беше казано, такива класификации са правени и преди това, но предвид динамиката на книжовната норма една нова класификация е особено необходима. При обособяването на типовете се взема предвид съвременното състояние на глаголната система. Представянето на формалните типове се извършва с оглед на нормативната граматика, т.е. въз основа на това кои граматични форми се приемат за правилни в днешния книжовен език. Тъй като езикът е динамична система - динамичният (нестатичният) характер на езика на всеки етап от неговото развитие е представен още от Р. Якобсон като езикова универсалия и като процес, който има „терапевтична функция“ за възстановяване на баланса на езиковата система (вж. Vachek, 2014, с. 56), съвременното формообразуване при глаголите се нуждае от прецизно описание, доколкото са налице промени спрямо предшестващия етап, представен и в академичната Граматика на съвременния български книжовен език (1983) и в правописните речници преди 2012 г.

Най-важните промени са свързани с дублетността, която е основен инструмент на кодификацията при отразяване на динамиката на книжовната норма. Това е една от причините, поради които се наблюдават различия с останалите класификации. От най-новите правописни речници са отстранени онези дублети, които са се оказали неперспективни от гледна точка на развитието на книжовния език, и оттук идва една част от разликите 
на предложената тук класификация с предишните. Тези разлики засягат основно дублетността при формите на някои глаголи, и по-специално при аористната и имперфектната основа (напр. отпаднала е дублетността при държах и държех; при аористните форми от типа вея $x$ и вя $x$, блея $x$ и бля $x$; при аористните причастия веял и вял, блеял и блял, като са оставени само формите вя $x$, бля $x$, вял, блял), и при ударението - отпаднала е например дублетността при глед $\underline{a}$ (с допускане ударението да се мести върху последната сричка във формите за мин. св. вр., за да се отграничат от формите за сегашно време). В същото време е кодифициран нов тип дублетност - напр. при форми за мин. несв. деятелно причастие на някои глаголи, каквито са крояли и кроели). Нормативният критерий позволява да се отчетат онези особености при формообразуването на глаголите, които отразяват актулното състояние на книжовната норма, фиксирано в единствения по рода си Обициален правописен речник на българския език. Глаголи (2016). Този речник има строго нормативен характер и отчита динамиката на граматичния развой от последните 50 г. Той изпълнява кодифицираща функция по отношение не само на правописа и правоговора, но и на граматиката на глаголите в българския книжовен език, затова именно той е взет предвид при обособяването на типовете.

Процедурата, по която се обособяват формообразувателните типове в българската глаголна лексика, включва три нива на категоризиране: 1) по морфологичен критерий, т.е. според състава на граматичните морфеми, които са три типа - темпорални тематични гласни, форманти и окончания (Topolińska, 2009, с. 154; Малджиева, 2009, с. 46; вж. и по-ранното изследване на Пашов, който дефинира три типа граматични суфикси, които се прибавят след видовия според него суфикс при глаголното формообразуване - тематични (темпорални) суфикси, формообразуващи суфикси $-x /$ - $и$ за имперфект, - $x /$ - за аорист, -л за минали деятелни причастия, -щ за сегашно

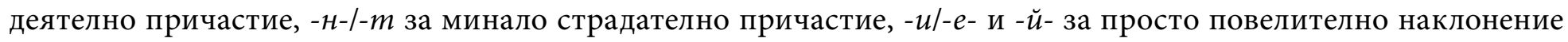
и окончания за лице и число и за род и число - Пашов, 1976, с. 49-50); 2) по видове морфонологични (регресивни) промени, кодирани в словообразувателната или в граматичната основа, и 3) по нормативен критерий (наличието на дублетност). Обособяването на отделните типове отчита и комбинаториката между репрезентации от различните нива. 
Темпоралните тематични гласни са примарен класификационен критерий при обособяването на формални класове при българските глаголи. Анализът на синтетичните глаголни форми във връзка с дистрибуцията на стойностите на тематичните грамеми - презентна, аористна и имперфектна, дава основание да предложим като първа стъпка при разпределянето на глаголната лексика по формообразувателни класове критерия комбинаторика на стойностите на трите вида тематични грамеми (вж. Станчева, 2018). Това позволява цялото множество от глаголни лексеми да се разпредели в 9 класа, изведени въз основа на емипиричното наблюдение. Така се избягва подялбата първо на спрежения, а след това на разреди в рамките на всяко спрежение, което според нас води до по-адекватна и хомогенна класификация на глаголните лексеми в българския език. Първоначално и най-общо е разпределението по класове, базирано на комбинаториката на стойностите на трите тематични суфикса, което представяме по-долу.

КЛАС 1. КОМБИНАТОРИКА -Е-Ф /-А-Х - $/$ /Е-Х - $($ (напр. бръсн-е-Ø/ бръсн-а-х/ лъг-а-х-Ø/ лъж-е-х-Ø; ве-е-Ø/ в-Ø-(')-а-х-Ø / ве-е-х-Ø; бле-е-Ø/ бл-Ø-(')-а-х-Ø / бле-е-х-Ø), ва-е-Ø/ ва-[й]-а-х/ ва-е-х- $\varnothing$ )

КЛАС 2. КОМБИНАТОРИКА -Е[рев'-а-х-Ø]; (напр. спр-е-Ø/ спр-я-х-Ø / спр-я-х-Ø [спр'-а-х-Ø])

КЛАС 3. КОМБИНАТОРИКА -Е-Ø /-О-Х-Ø /-А-Х-Ø (графично -а-х или -я-х) (напр. вле-ч-е- $/$ вляк-о-х-Ø / влеч-а-х- $\varnothing$; чет-е-

КЛАС 4. КОМБИНАТОРИКА -Е-Ø/-О-Х/-Е-Х-Ø (напр. дойд-е- $/$ дойд-о-х- $/$ дойд-е-х- $)$

КЛАС 5. КОМБИНАТОРИКА -Е-Ø/-Ø-Х/-Е-Х-Ø (напр. би-е-Ø/ би-Ø-х-Ø / би-е-х-Ø, жела-е-Ø/ жела-Ø-х-Ø / жела-е-х-Ø)

КЛАС 6. КОМБИНАТОРИКА -И-Ø /-И-Х-Ø /-А-Х-Ø (графично -я-хили -а-х): (напр. леп-и я-х- $\varnothing$; умнож-и- $\varnothing /$ умнож-и-х- $\varnothing /$ умнож-а-х- $\varnothing)$ 


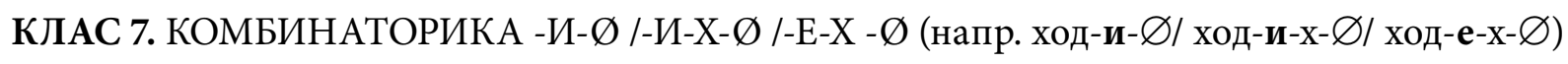

КЛАС 8. КОМБИНАТОРИКА -И-Ø /-А-Х-Ø /-А-Х -

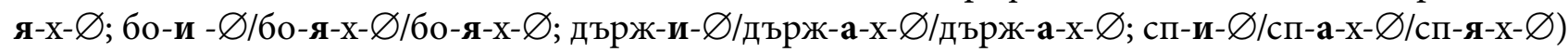

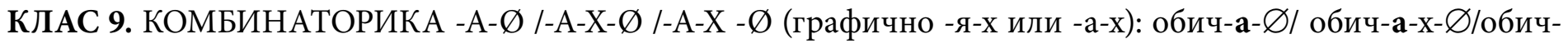

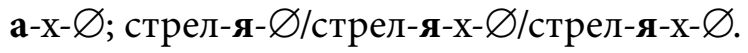

В рамките на всеки от деветте класа се обособяват формообразувателни типове въз основа на морфонологични алтернации (редувания) при образуването на формите на глаголната лексема. Тези редувания са резултат от взаимодействието на граматичните и словообразувателните морфеми в границите на дадена форма на лексемата. Критерий за обособяването на типове е и наличието на дублетни форми при реализацията на грамемите.

Формообразувателните глаголни типове при първо спрежение се описват въз основа на набор от диагностични форми. Този набор е изведен според принципите на изследването на формообразуването при глаголите. Необходимостта от такива диагностични форми е свързана с факта, че значителна част от глаголните лексеми в български се реализира с по 42 синтетични форми. Доколкото обаче не всички те са релевантни за обособяването на даден формообразувателен тип, предлагаме максимално информативен и в същото време икономичен набор от форми. Той се основава най-напред върху комбинаториката на стойностите на темпоралните тематични грамеми: за 3 л. ед. ч. в презенс, 1 л. ед. ч. в аорист и 1 л. ед. ч. в имперфект. Тази комбинаторика е залегнала в основата на обособяването на формообразувателните типове при глаголните лексеми в българския книжовен език.

Съществен за обособяването на отделните типове е и наборът от форми, образувани с различните граматични форманти. При това се отчитат два факта. Първият е + /- форма с формант -щ и + /- форма със стойности на форманта -H-/-m-. Ако формообразуващ формант, характеризиращ структурата на дадена форма, има повече от една стойност, като диагностични се приемат всички тези стойности (напр. стойностите на форманта -H-/-m- 
във формата за м. р. ед. ч.: напр. каз-a-н/ бръсн-a-m или на императивния формант за 2 л. ед. ч. -u-/-й: $\kappa a ж-u / n e-\breve{u}$ и за 2 л. мн. ч. -е-/-й: $к a \nLeftarrow-\boldsymbol{e}-m e / n e-\breve{u}-m e)$.

Макар всички глаголи в български да образуват форми с формант -л от аористна и имперфектна основа, тези форми също се взимат предвид с оглед на това, че при тях се наблюдават редица морфонологични редувания, резултат от взаимодействието на словообразувателната основа с граматичните морфеми (напр. чет- $a$, но чеØ-л). Освен двете форми с формант -л в м.р. ед. ч. като диагностична се взема и формата за мн.ч. от имперфектната основа, тъй като при някои лексеми в тези форми е кодифицирана дублетност (напр. кро-я-л-и и кро-е-л-и).

За диагностична се приема и формата за имперфект в 3 л. ед. ч. заради признака $+/-$ редуване Я $\rightarrow \mathrm{E}$ (напр. чет-я-x-чет-е-и-e).

Формата за 1 л. мн. ч. сег. вр. също може да бъде диагностична по две причини. От една страна, тя служи за обособяването на множеството на глаголите с неизменяеми форми за лице и число (т. е. безлични глаголи: напр. съмва, но не и ${ }^{\star}$ съмваме ), при които тази форма отсъства. От друга страна, тя служи и за обособяването на формообразувателни типове при глаголните лексеми с форми само за 3 л. ед. ч. и за 1, 2 и 3 л. мн. ч. (напр. изпозаспахме, но не и ${ }^{\star}$ изиозаспах).

Към тези форми се добавя и формата за 1 л. ед. ч. сег. вр. поради факта, че при част от глаголната лексика тази форма се противопоставя на останалите презентни форми за ед. ч. по редуването мекост - твърдост в корена на словообразувателната основа.

И така, подбрани са 12 диагностични форми, необходими и достатъчни за обобосбяването на формообразувателните типове в рамките на глаголната лексика, като условният ред, в който се представят тук, е следният:

1. презентна форма за 1 л. ед. ч. (основна форма на глагола)

2. презентна форма за 3 л. ед. ч.

3. презентна форма за 1 л. мн. ч.

4. аористна форма за 1 л. ед. ч. 
5. форма за имперфект в 1 л. ед. ч.

6. формата за ед. ч. м. р. с формант -л, образувана от аористната основа

7. формата за м. р. ед. ч. с формант -л, образувана от имперфектната основа

8. формата за мн. ч. с формант -л, образувана от имперфектната основа

9. форма за ед. ч. м. р. със стойности на форманта -н- или -т-

10. форма за ед. ч. м. р. със стойност на форманта -щ-

11. форми със стойности на форманта -и-/-е- или -й

Както се вижда от обособените по-горе девет класа според комбинаториката на стойностите на темпоралните тематични грамеми, глаголите от първо спрежение обхващат първите пет класа. В съвременното състояние на езика глаголите от първо спрежение обединяват глаголите от три старобългарски спрежения (Теодоров-Балан, 1940, с. 217), което обяснява и голямото разнообразие от формообразувателни типове при тях. По-нататък като илюстрация на модела на настоящата класификация ще представим онези формални типове, които попадат в обхвата на обособения тук Клас 1. с комбинаторика E-Ø /-A-X -Ø /-E-X-Ø на тематичните темпорални грамеми.

ТИП 1 - налице са всички диагностични форми, пипсват морфонологични редувания. Наличие на форма със стойност на форманта -m-: БР $\underline{\mathrm{ZCHA}}$

\begin{tabular}{|c|c|c|c|c|c|c|c|c|c|c|c|}
\hline $\begin{array}{l}\text { 1. л. ед. } \\
\text { ч. сег. вр. }\end{array}$ & $\begin{array}{l}\text { 3. л. ед. ч. } \\
\text { сег. вр. }\end{array}$ & $\begin{array}{l}\text { 1. л. мн.ч. } \\
\text { сег. вр. }\end{array}$ & $\begin{array}{l}1 \text { л. ед. ч. } \\
\text { мин. св. } \\
\text { време }\end{array}$ & $\begin{array}{l}1 \text { л. ед. ч. } \\
\text { мин. несв. } \\
\text { време }\end{array}$ & $\begin{array}{l}3 \text { л. ед. ч. } \\
\text { мин. несв. } \\
\text { време }\end{array}$ & $\begin{array}{l}\text { М. р. ед. ч. } \\
\text { с формант -л- от } \\
\text { аористна основа }\end{array}$ & $\begin{array}{l}\text { М. р. ед. ч. с фор- } \\
\text { мант -л- от импер- } \\
\text { фектна основа }\end{array}$ & $\begin{array}{l}\text { Мн. ч. с формант } \\
\text {-л- от имперфек- } \\
\text { тна основа }\end{array}$ & $\begin{array}{l}\text { М. р. ед. ч. } \\
\text { с формант } \\
\text { - } / \text { /-m- }\end{array}$ & $\begin{array}{l}\text { М. р. ед. ч. } \\
\text { с формант } \\
-\boldsymbol{u}_{-}\end{array}$ & $\begin{array}{l}\text { Форми с импера- } \\
\text { тивен формант }\end{array}$ \\
\hline 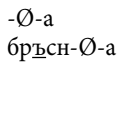 & $\begin{array}{l}\text { - е- } \varnothing \\
\text { бръсн-е-Ø }\end{array}$ & $\begin{array}{l}-е-м \\
\text { бръсн-е-м }\end{array}$ & $\begin{array}{l}-a-x-\varnothing \\
\text { бръсн-a- } \\
x-\varnothing\end{array}$ & $\begin{array}{l}-e-x-\varnothing \\
\text { бръсн-e- } \\
x-\varnothing\end{array}$ & $\begin{array}{l}\text {-е-ш-е } \\
\text { бръсн-е- } \\
\text { ш-е }\end{array}$ & $\begin{array}{l}\text {-а-л- } \varnothing \\
\text { бръсн-а-л- }\end{array}$ & $\begin{array}{l}\text {-е-л- } \varnothing \\
\text { бръсн-е-л- } \varnothing\end{array}$ & $\begin{array}{l}\text {-е-л-и } \\
\text { бръсн-е-л-и }\end{array}$ & $\begin{array}{l}-\mathrm{a}-\mathrm{T}-\varnothing \\
\text { бръсн-а- } \\
\text { т- }\end{array}$ & $\begin{array}{l}\text {-е-щ- } \varnothing \\
\text { бръсн-е- } \\
\text { щ- }\end{array}$ & $\begin{array}{l}\text { - } \emptyset \text {-ѝ- } \varnothing, \\
\text {-Ø-ѐ-те } \\
\text { бръсн- } \varnothing \text {-ѝ- } \varnothing \\
\text { бръсн- } \varnothing \text {-ѐ-те }\end{array}$ \\
\hline
\end{tabular}


ТИП 2 - обособява се от ТИП 1 въз основа на стойността -н- на форманта за минало страдателно причастие (този тип е едноелементно множество): ВЕЗА

\begin{tabular}{|c|c|c|c|c|c|c|c|c|c|c|c|}
\hline $\begin{array}{l}\text { 1. л. ед. } \\
\text { ч. сег. вр. }\end{array}$ & $\begin{array}{l}\text { 3. л. ед. ч. } \\
\text { сег. вр. }\end{array}$ & $\begin{array}{l}\text { 1. л. мн.ч. } \\
\text { сег. вр. }\end{array}$ & $\begin{array}{l}1 \text { л. ед. ч. } \\
\text { мин. св. } \\
\text { време }\end{array}$ & $\begin{array}{l}1 \text { л. ед. ч. } \\
\text { мин. несв. } \\
\text { време }\end{array}$ & $\begin{array}{l}3 \text { л. ед. ч. } \\
\text { мин. несв. } \\
\text { време }\end{array}$ & $\begin{array}{l}\text { М.р. ед. ч. } \\
\text { с формант -л- от } \\
\text { аористна основа }\end{array}$ & $\begin{array}{l}\text { М. р. ед. ч. с фор- } \\
\text { мант -л- от импер- } \\
\text { фектна основа }\end{array}$ & $\begin{array}{l}\text { Мн. ч. с формант } \\
\text {-л- от имперфек- } \\
\text { тна основа }\end{array}$ & $\begin{array}{l}\text { М. р. ед. ч. } \\
\text { с формант } \\
\text {-H/-т- }\end{array}$ & $\begin{array}{l}\text { М. р. ед. ч. } \\
\text { с формант } \\
\text {-щ- }\end{array}$ & $\begin{array}{l}\text { Форми с импера- } \\
\text { тивен формант }\end{array}$ \\
\hline $\begin{array}{l}-\varnothing-\mathrm{a} \\
\text { вѐз- } \varnothing-\mathrm{a}\end{array}$ & $\begin{array}{l}\text { - е- } \varnothing \\
\text { вѐз-е-Ø }\end{array}$ & $\begin{array}{l}-\mathrm{e}-\mathrm{M} \\
\text { вѐз-е-м }\end{array}$ & $\begin{array}{l}\text {-a-x-Ø } \\
\text { вѐз-a-x- } \varnothing\end{array}$ & $\begin{array}{l}\text {-e-x-Ø } \\
\text { вѐз-e-x- } \varnothing\end{array}$ & $\begin{array}{l}\text {-e-ш-е } \\
\text { вѐз-е-ш-е }\end{array}$ & $\begin{array}{l}\text {-а-л- } \varnothing \\
\text { вёз-а-л- } \varnothing\end{array}$ & $\begin{array}{l}\text {-е-л- } \varnothing \\
\text { вёз-е-л- } \varnothing\end{array}$ & $\begin{array}{l}\text {-е-л-и } \\
\text { вѐз-е-л-и }\end{array}$ & $\begin{array}{l}\text {-а-н-Ø } \\
\text { вёз-а-н- } \varnothing\end{array}$ & $\begin{array}{l}\text {-е-щ-Ø } \\
\text { вѐз-е-щ-Ø }\end{array}$ & 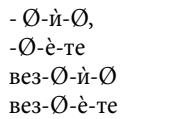 \\
\hline
\end{tabular}

ТИП 3 - обособява се от ТИП 1 въз основа на липсата на форми с формант със стойности -н-/-m-: МРЪЗНА

\begin{tabular}{|c|c|c|c|c|c|c|c|c|c|c|c|}
\hline $\begin{array}{l}\text { 1. л. ед. } \\
\text { ч. сег. вр. }\end{array}$ & $\begin{array}{l}\text { 3. л. ед. ч. } \\
\text { сег. вр. }\end{array}$ & $\begin{array}{l}\text { 1. л. мн.ч. } \\
\text { сег. вр. }\end{array}$ & $\begin{array}{l}1 \text { л. ед. ч. } \\
\text { мин. св. } \\
\text { време }\end{array}$ & $\begin{array}{l}1 \text { л. ед. ч. } \\
\text { мин. несв. } \\
\text { време }\end{array}$ & $\begin{array}{l}3 \text { л. ед. ч. } \\
\text { мин. несв. } \\
\text { време }\end{array}$ & $\begin{array}{l}\text { М. р. ед. ч. с фор- } \\
\text { мант -л- от аорис- } \\
\text { тна основа }\end{array}$ & $\begin{array}{l}\text { М. р. ед. ч. с фор- } \\
\text { мант -л- от импер- } \\
\text { фектна основа }\end{array}$ & $\begin{array}{l}\text { Мн. ч. с формант } \\
\text {-л- от имперфек- } \\
\text { тна основа }\end{array}$ & $\begin{array}{l}\text { М. р. ед. ч. } \\
\text { с формант } \\
\text {-н/-т- }\end{array}$ & $\begin{array}{l}\text { М. р. ед. ч. } \\
\text { с формант } \\
\text {-щ- }\end{array}$ & $\begin{array}{l}\text { Форми с импера- } \\
\text { тивен формант }\end{array}$ \\
\hline $\begin{array}{l}-\varnothing-\mathrm{a} \\
\text { мръ-- } \\
\text { 3н-Ø-а }\end{array}$ & $\begin{array}{l}\text { e- } \emptyset \\
\text { мръ- } \\
3 \mathrm{H}^{-}-\mathrm{e}-\varnothing\end{array}$ & $\begin{array}{l}-е-м \\
\text { мръ3н-е-м }\end{array}$ & $\begin{array}{l}-a-x-\varnothing \\
\text { мръзн-а- } \\
\text { х-Ø }\end{array}$ & $\begin{array}{l}\text {-e-х-Ø } \\
\text { мръзн-е- } \\
\text { х-Ø }\end{array}$ & $\begin{array}{l}\text {-е-ш-е } \\
\text { мръзн-е- } \\
\text { ш-е }\end{array}$ & $\begin{array}{l}\text {-а-л- } \emptyset \\
\text { мръзн-а-л- } \varnothing\end{array}$ & $\begin{array}{l}\text {-е-л- } \varnothing \\
\text { мръзн-е-л- } \varnothing\end{array}$ & $\begin{array}{l}\text {-е-л-и } \\
\text { мръзн-е-л-и }\end{array}$ & - & $\begin{array}{l}\text {-е-щ-Ø } \\
\text { мръззн-е- } \\
\text { щ-Ø }\end{array}$ & $\begin{array}{l}\text {-Ø-й-Ø; } \\
\text {-Ø-ѐ-те } \\
\text { мръзн- Ø-й-Ø; } \\
\text { мръзн-Ø-ѐ-те }\end{array}$ \\
\hline
\end{tabular}

ТИП 4 - обособява се от ТИП 1 въз основа на липсата на форми с формант -щ-: ВЪРНА

\begin{tabular}{|c|c|c|c|c|c|c|c|c|c|c|c|}
\hline $\begin{array}{l}\text { 1. л. ед. } \\
\text { ч. сег. вр. }\end{array}$ & $\begin{array}{l}\text { 3. л. ед. ч. } \\
\text { сег. вр. }\end{array}$ & $\begin{array}{l}\text { 1. л. мн.ч. } \\
\text { сег. вр. }\end{array}$ & $\begin{array}{l}1 \text { л. ед. ч. } \\
\text { мин. св. } \\
\text { време }\end{array}$ & $\begin{array}{l}1 \text { л. ед. ч. } \\
\text { мин. несв. } \\
\text { време }\end{array}$ & $\begin{array}{l}3 \text { л. ед. ч. } \\
\text { мин. несв. } \\
\text { време }\end{array}$ & $\begin{array}{l}\text { М. р. ед. ч. } \\
\text { с формант -л- от } \\
\text { аористна основа }\end{array}$ & $\begin{array}{l}\text { М. р. ед. ч. с фор- } \\
\text { мант -л- от импер- } \\
\text { фектна основа }\end{array}$ & $\begin{array}{l}\text { Мн. ч. с формант } \\
\text {-л- от имперфек- } \\
\text { тна основа }\end{array}$ & $\begin{array}{l}\text { М. р. ед. ч. } \\
\text { с формант } \\
\text {-н/-т- }\end{array}$ & $\begin{array}{l}\text { М. р. ед. ч. } \\
\text { с формант } \\
\text {-щ- }\end{array}$ & $\begin{array}{l}\text { Форми с импера- } \\
\text { тивен формант }\end{array}$ \\
\hline $\begin{array}{l}-\varnothing-\mathrm{a} \\
\text { върн-Ø-а }\end{array}$ & $\begin{array}{l}-\varnothing \\
\text { върн-е- } \varnothing\end{array}$ & $\begin{array}{l}\text {-е-м } \\
\text { върн-е-м }\end{array}$ & $\begin{array}{l}\text {-a-x-Ø } \\
\text { върн-а- } \\
\text { х-Ø }\end{array}$ & $\begin{array}{l}\text {-е-х-Ø } \\
\text { върн-е- } \\
\text { х-Ø }\end{array}$ & $\begin{array}{l}\text {-е-ш-е } \\
\text { върн } \\
-е-ш-е\end{array}$ & -а-л- Ø върн-а-л- & $\begin{array}{l}\text {-е-л-Ø } \\
\text { върн-е-л-Ø }\end{array}$ & $\begin{array}{l}\text {-е-л-и } \\
\text { върн-е-л-и }\end{array}$ & $\begin{array}{l}\text {-а-т-Ø } \\
\text { върн-а- } \\
\text { т-Ø }\end{array}$ & - & 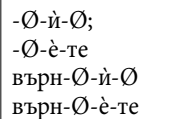 \\
\hline
\end{tabular}


ТИП 5 - обособява се от ТИП 2 по липсата на форми с формант със стойност на форманта -н- (едноелементно множество): ИЗВЕЗА

\begin{tabular}{|c|c|c|c|c|c|c|c|c|c|c|c|}
\hline $\begin{array}{l}\text { 1. л. ед. } \\
\text { ч. сег. вр. }\end{array}$ & $\begin{array}{l}\text { 3. л. ед. ч. } \\
\text { сег. вр. }\end{array}$ & $\begin{array}{l}\text { 1. л. мн.ч. } \\
\text { сег. вр. }\end{array}$ & $\begin{array}{l}1 \text { л. ед. ч. } \\
\text { мин. св. } \\
\text { време }\end{array}$ & $\begin{array}{l}1 \text { л. ед. ч. } \\
\text { мин. несв. } \\
\text { време }\end{array}$ & $\begin{array}{l}3 \text { л. ед. ч. } \\
\text { мин. несв. } \\
\text { време }\end{array}$ & $\begin{array}{l}\text { М. р. ед. ч. } \\
\text { с формант -л- от } \\
\text { аористна основа }\end{array}$ & $\begin{array}{l}\text { М. p. ед. ч. с фор- } \\
\text { мант } \\
\text {-л- от имперфек- } \\
\text { тна основа }\end{array}$ & $\begin{array}{l}\text { Мн. ч. с формант } \\
\text {-л- от имперфек- } \\
\text { тна основа }\end{array}$ & $\begin{array}{l}\text { М. р. ед. ч. } \\
\text { с формант } \\
\text {-н/-т- }\end{array}$ & $\begin{array}{l}\text { М. р. ед. ч. } \\
\text { с формант } \\
\text {-щ- }\end{array}$ & $\begin{array}{l}\text { Форми с импера- } \\
\text { тивен формант }\end{array}$ \\
\hline $\begin{array}{l}-\varnothing \text {-а } \\
\text { извѐз-Ø-а }\end{array}$ & $\begin{array}{l}\text { - е- } \varnothing \\
\text { извѐз-е- } \varnothing\end{array}$ & $\begin{array}{l}\text {-е-м } \\
\text { извѐз-е-м }\end{array}$ & $\begin{array}{l}\text {-а-х- } \varnothing \\
\text { извёз-а- } \\
\text { x-Ø }\end{array}$ & $\begin{array}{l}\text {-e-x- } \varnothing \\
\text { извѐз-е- } \\
x-\varnothing\end{array}$ & $\begin{array}{l}\text {-е-ш-е } \\
\text { извѐз-е- } \\
\text { ш-е }\end{array}$ & $\begin{array}{l}\text {-а-л-Ø } \\
\text { извѐз-а-л- }\end{array}$ & $\begin{array}{l}\text {-е-л- } \varnothing \\
\text { извѐз-е-л- }\end{array}$ & $\begin{array}{l}\text {-е-л-и } \\
\text { извѐз-е-л-и }\end{array}$ & $\begin{array}{l}\text {-а-н- } \varnothing \\
\text { извѐз- } \\
\text { a-н- } \varnothing\end{array}$ & - & 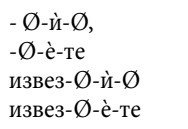 \\
\hline
\end{tabular}

ТИП 6 - обособява се от ТИП 1 по липсата на форми с форманти със стойности -н-/-m- и -щ-: РЕВНА

\begin{tabular}{|c|c|c|c|c|c|c|c|c|c|c|c|}
\hline $\begin{array}{l}\text { 1. л. ед. } \\
\text { ч. сег. вр. }\end{array}$ & $\begin{array}{l}\text { 3. л. ед. ч. } \\
\text { сег. вр. }\end{array}$ & $\begin{array}{l}\text { 1. л. мн.ч. } \\
\text { сег. вр. }\end{array}$ & $\begin{array}{l}1 \text { л. ед. ч. } \\
\text { мин. св. } \\
\text { време }\end{array}$ & $\begin{array}{l}1 \text { л. ед. ч. } \\
\text { мин. несв. } \\
\text { време }\end{array}$ & $\begin{array}{l}3 \text { л. ед. ч. } \\
\text { мин. несв. } \\
\text { време }\end{array}$ & $\begin{array}{l}\text { М. р. ед. ч. } \\
\text { с формант -л- от } \\
\text { аористна основа }\end{array}$ & $\begin{array}{l}\text { М. р. ед. ч. с фор- } \\
\text { мант -л- от импер- } \\
\text { фектна основа }\end{array}$ & $\begin{array}{l}\text { Мн. ч. с формант } \\
\text {-л- от имперфек- } \\
\text { тна основа }\end{array}$ & $\begin{array}{l}\text { М. р. ед. ч. } \\
\text { с формант } \\
\text {-н/-т- }\end{array}$ & $\begin{array}{l}\text { М.р. ед. ч. } \\
\text { с формант } \\
\text {-щ- }\end{array}$ & $\begin{array}{l}\text { Форми с импера- } \\
\text { тивен формант }\end{array}$ \\
\hline $\begin{array}{l}-\emptyset-\mathrm{a} \\
\text { рѐвн- } \emptyset-\mathrm{a}\end{array}$ & $\begin{array}{l}\text { - е- } \varnothing \\
\text { рѐвн-е-Ø }\end{array}$ & $\begin{array}{l}\text {-e-M } \\
\text { рѐвH-e-м }\end{array}$ & $\begin{array}{l}\text {-a-x- } \varnothing \\
\text { pèBH-a- } \\
x-\varnothing\end{array}$ & $\begin{array}{l}-e-x-\varnothing \\
\text { pèsH-e- } \\
x-\varnothing\end{array}$ & $\begin{array}{l}\text {-e-ш-е } \\
\text { pèвн-e- } \\
\text { ш-е }\end{array}$ & -а-л-Ø рѐвн-а-л-Ø & $\begin{array}{l}\text {-е-л-Ø } \\
\text { рѐвн-е-л-Ø }\end{array}$ & $\begin{array}{l}\text {-е-л-и } \\
\text { рѐвн-е-л-и }\end{array}$ & - & - & $\begin{array}{l}\text { - } \text {-й- }, \\
\text {-Ø-ѐ-те } \\
\text { ревн-Ø-ѝ-Ø } \\
\text { ревн-Ø-ѐ-те }\end{array}$ \\
\hline
\end{tabular}

ТИП 7 - обособява се от ТИП 1 по наличие на форми само за 3 л. ед. и 1, 2 и 3 л. мн. ч.: ИЗПОСЪХНЕ

\begin{tabular}{|c|c|c|c|c|c|c|c|c|c|c|c|}
\hline $\begin{array}{l}\text { 1. л. ед. } \\
\text { ч. сег. вр. }\end{array}$ & $\begin{array}{l}\text { 3. л. ед. ч. } \\
\text { сег. вр. }\end{array}$ & $\begin{array}{l}\text { 1. л. мн.ч. } \\
\text { сег. вр. }\end{array}$ & $\begin{array}{l}1 \text { л. ед. ч. } \\
\text { мин. св. } \\
\text { време }\end{array}$ & $\begin{array}{l}1 \text { л.ед. ч. } \\
\text { мин. несв. } \\
\text { време }\end{array}$ & $\begin{array}{l}3 \text { л. ед. ч. } \\
\text { мин. несв. } \\
\text { време }\end{array}$ & $\begin{array}{l}\text { М. р. ед. ч. } \\
\text { с формант -л- от } \\
\text { аористна основа }\end{array}$ & $\begin{array}{l}\text { М. р. ед. ч. с фор- } \\
\text { мант } \\
\text {-л- от имперфек- } \\
\text { тна основа }\end{array}$ & $\begin{array}{l}\text { Мн. ч. с формант } \\
\text {-л- от имперфек- } \\
\text { тна основа }\end{array}$ & $\begin{array}{l}\text { М. р. ед. ч. } \\
\text { с формант } \\
\text {-н/-т- }\end{array}$ & $\begin{array}{l}\text { М. р. ед. ч. } \\
\text { с формант } \\
\text {-щ- }\end{array}$ & $\begin{array}{l}\text { Форми с импера- } \\
\text { тивен формант }\end{array}$ \\
\hline - & $\begin{array}{l}\text {-е- } \varnothing \\
\text { изпо- } \\
\text { съхн-е- } \varnothing\end{array}$ & $\begin{array}{l}-е-м \\
\text { изпосъх- } \\
\text { не-м }\end{array}$ & - & - & $\begin{array}{l}\text {-е-ш-е } \\
\text { изпосъхн- } \\
\text { е-ш-е }\end{array}$ & $\begin{array}{l}\text {-а-л- } ~ \\
\text { изпосъхн-а-л- }\end{array}$ & $\begin{array}{l}\text {-е-л- } \varnothing \\
\text { изпосъххн-е-л- } \varnothing\end{array}$ & $\begin{array}{l}\text {-е-л-и } \\
\text { изпосъхн-е-л-и }\end{array}$ & - & - & $\begin{array}{l}\text {-Ø-й- }, \\
\text {-Ø-ѐ-те } \\
\text { изпосъхн- Ø-й- } \\
\text { изпосъхн-Ø-ѐ-те }\end{array}$ \\
\hline
\end{tabular}


ТИП 8 - обособява се от ТИП 4 по наличие на преглас Я $\rightarrow$ В в корена на формите, образувани от сегашната и имперфектната основа: ВДЯНА

\begin{tabular}{|c|c|c|c|c|c|c|c|c|c|c|c|}
\hline $\begin{array}{l}\text { 1. л. ед. } \\
\text { ч. сег. вр. }\end{array}$ & $\begin{array}{l}\text { 3. л. ед. ч. } \\
\text { сег. вр. }\end{array}$ & $\begin{array}{l}\text { 1. л. мн.ч. } \\
\text { сег. вр. }\end{array}$ & $\begin{array}{l}1 \text { л. ед. ч. } \\
\text { мин. св. } \\
\text { време }\end{array}$ & $\begin{array}{l}1 \text { л. ед. ч. } \\
\text { мин. несв. } \\
\text { време }\end{array}$ & $\begin{array}{l}3 \text { л. ед. ч. } \\
\text { мин. несв. } \\
\text { време }\end{array}$ & $\begin{array}{l}\text { М. р. ед. ч. } \\
\text { с формант -л- от } \\
\text { аористна основа }\end{array}$ & $\begin{array}{l}\text { М. р. ед. ч. с фор- } \\
\text { мант -л- от импер- } \\
\text { фектна основа }\end{array}$ & $\begin{array}{l}\text { Мн. ч. с формант } \\
\text {-л- от имперфек- } \\
\text { тна основа }\end{array}$ & $\begin{array}{l}\text { М. р. ед. ч. } \\
\text { с формант } \\
\text {-н/-т- }\end{array}$ & $\begin{array}{l}\text { М. р. ед. ч. } \\
\text { с формант } \\
\text {-щ- }\end{array}$ & $\begin{array}{l}\text { Форми с импера- } \\
\text { тивен формант }\end{array}$ \\
\hline $\begin{array}{l}-\varnothing \text {-а } \\
\text { вдян-Ø-а }\end{array}$ & $\begin{array}{l}\text {-е-Ø } \\
\text { вден-е- } \varnothing\end{array}$ & $\begin{array}{l}-\mathrm{e}-\mathrm{M} \\
\text { вден-е-м }\end{array}$ & $\begin{array}{l}-a-x-\varnothing \\
\text { вдян-а-х }\end{array}$ & $\begin{array}{l}\text {-е-х- } \varnothing \\
\text { вден-е-х- } \varnothing\end{array}$ & $\begin{array}{l}\text {-е-ш-е } \\
\text { вден-е-ш-е }\end{array}$ & $\begin{array}{l}\text {-а-л-Ø } \\
\text { вдян-а-л-Ø }\end{array}$ & $\begin{array}{l}\text {-е-л- } \varnothing \\
\text { вден-е-л- }\end{array}$ & $\begin{array}{l}\text {-е-л-и } \\
\text { вден-е-л-и }\end{array}$ & $\begin{array}{l}\text {-а-т- } \varnothing \\
\text { вдян-а- } \\
\text { т- } \varnothing\end{array}$ & - & $\begin{array}{l}\text {-Ø-й-Ø, } \\
\text {-Ø-ѐ-те } \\
\text { вден-Ø-й-Ø } \\
\text { вден-Ø-ѐ-те }\end{array}$ \\
\hline
\end{tabular}

ТИП 9 - отличава се от ТИП 8 по наличие на дублетност в основната форма и формите от сегашна и аористна основа: БЯЛНА СЕ и БЕЛНА СЕ

\begin{tabular}{|c|c|c|c|c|c|c|c|c|c|c|c|}
\hline $\begin{array}{l}\text { 1. л. ед. } \\
\text { ч. сег. вр. }\end{array}$ & $\begin{array}{l}\text { 3. л. ед. ч. } \\
\text { сег. вр. }\end{array}$ & $\begin{array}{l}\text { 1. л. мн.ч. } \\
\text { сег. вр. }\end{array}$ & $\begin{array}{l}1 \text { л. ед. ч. } \\
\text { мин. св. } \\
\text { време }\end{array}$ & $\begin{array}{l}1 \text { л. ед. ч. } \\
\text { мин. несв. } \\
\text { време }\end{array}$ & $\begin{array}{l}3 \text { л. ед. ч. } \\
\text { мин. несв. } \\
\text { време }\end{array}$ & $\begin{array}{l}\text { М. р. ед. ч. } \\
\text { с формант -л- от } \\
\text { аористна основа }\end{array}$ & $\begin{array}{l}\text { М. р. ед. ч. с фор- } \\
\text { мант -л- от импер- } \\
\text { фектна основа }\end{array}$ & $\begin{array}{l}\text { Мн. ч. с формант } \\
\text {-л- от имперфек- } \\
\text { тна основа }\end{array}$ & $\begin{array}{l}\text { М. р. ед. ч. } \\
\text { с формант } \\
\text {-н/-т- }\end{array}$ & $\begin{array}{l}\text { М. р. ед. ч. } \\
\text { с формант } \\
\text {-щ- }\end{array}$ & $\begin{array}{l}\text { Форми с импера- } \\
\text { тивен формант }\end{array}$ \\
\hline $\begin{array}{l}-\varnothing \text {-а } \\
\text { бялн-Ø-а се } \\
\text { и } \\
\text { белн-Ø-а се }\end{array}$ & $\begin{array}{l}\text {-е- } \varnothing \\
\text { белн-е- } \varnothing\end{array}$ & $\begin{array}{l}-е-м \\
\text { белн-е-м }\end{array}$ & $\begin{array}{l}\text {-a-х- } \\
\text { бялн-а-х- } \varnothing \\
\text { и } \\
\text { белн-а-х Ø }\end{array}$ & $\begin{array}{l}-е-x-\varnothing \\
\text { белн-е- } \\
\text { х- } \varnothing\end{array}$ & $\begin{array}{l}\text {-е-ш-е } \\
\text { белн } \\
-е-ш-е\end{array}$ & $\begin{array}{l}\text {-а-л- } \\
\text { бялн-а-л- } \\
\text { и } \\
\text { белн-а-л- } \varnothing\end{array}$ & $\begin{array}{l}\text {-е-л- } \varnothing \\
\text { белн-е-л-Ø }\end{array}$ & $\begin{array}{l}\text {-е-л-и } \\
\text { белн-е-л-и }\end{array}$ & $\begin{array}{l}\text {-а-т- } \varnothing \\
\text { бялна-т- } \\
\text { и } \\
\text { белна-т- } \varnothing\end{array}$ & - & $\begin{array}{l}\text {-Ø-ѝ- }, \\
\text {-Ø-ѐ-те } \\
\text { белн-Ø-й-Ø се } \\
\text { белн-Ø-ѐ-те се }\end{array}$ \\
\hline
\end{tabular}

ТИП 10 - отличава се от ТИП 9 по липса на форми със стойности на форманта -н-/-т-: ВЯСНА СЕ И ВЕСНА СЕ

\begin{tabular}{|c|c|c|c|c|c|c|c|c|c|c|c|}
\hline $\begin{array}{l}\text { 1. л. ед. } \\
\text { ч. сег. вр. }\end{array}$ & $\begin{array}{l}\text { 3. л. ед. ч. } \\
\text { сег. вр. }\end{array}$ & $\begin{array}{l}\text { 1. л. мн.ч. } \\
\text { сег. вр. }\end{array}$ & $\begin{array}{l}1 \text { л. ед. ч. } \\
\text { мин. св. } \\
\text { време }\end{array}$ & $\begin{array}{l}1 \text { л. ед. ч. } \\
\text { мин. несв. } \\
\text { време }\end{array}$ & $\begin{array}{l}3 \text { л. ед. ч. } \\
\text { мин. несв. } \\
\text { време }\end{array}$ & $\begin{array}{l}\text { М. р. ед. ч. } \\
\text { с формант -л- от } \\
\text { аористна основа }\end{array}$ & $\begin{array}{l}\text { М. р. ед. ч. с фор- } \\
\text { мант } \\
\text {-л- от имперфек- } \\
\text { тна основа }\end{array}$ & $\begin{array}{l}\text { Мн. ч. с формант } \\
\text {-л- от имперфек- } \\
\text { тна основа }\end{array}$ & $\begin{array}{l}\text { М. р. ед. ч. } \\
\text { с формант } \\
\text {-н/-т- }\end{array}$ & $\begin{array}{l}\text { М. р. ед. ч. } \\
\text { с формант } \\
\text {-щ- }\end{array}$ & $\begin{array}{l}\text { Форми с импера- } \\
\text { тивен формант }\end{array}$ \\
\hline $\begin{array}{l}-\varnothing \text {-а } \\
\text { вясн- } Ø \text {-а се } \\
\text { и } \\
\text { вѐсн-Ø-а }\end{array}$ & $\begin{array}{l}\text {-е- } \varnothing \\
\text { вѐсн-е- } \varnothing\end{array}$ & $\begin{array}{l}-\mathrm{e}-\mathrm{M} \\
\text { вѐсн-е-м }\end{array}$ & $\begin{array}{l}\text {-a-x- } \varnothing \\
\text { вясн-a-x- } \varnothing \\
\text { и } \\
\text { вѐсн-a-x- } \varnothing\end{array}$ & $\begin{array}{l}\text {-e-x- } \varnothing \\
\text { вѐсн-e-x- } \varnothing\end{array}$ & $\begin{array}{l}\text {-е-ш-е } \\
\text { вѐсн-е-ше }\end{array}$ & $\begin{array}{l}\text {-а-л- } \\
\text { вясн-а-л- } \\
\text { и } \\
\text { весн-а-л- } \varnothing\end{array}$ & $\begin{array}{l}\text {-е-л- } \varnothing \\
\text { вѐсн-е-л- }\end{array}$ & $\begin{array}{l}\text {-е-л-и } \\
\text { вѐсн-е-л-и }\end{array}$ & - & - & 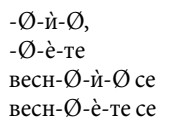 \\
\hline
\end{tabular}


ТИП 11 - обособява се от ТИП 2 по наличие на редуване Ж $\rightarrow$ в корена на формите, образувани от аористната основа: ЛЪЖА

\begin{tabular}{|c|c|c|c|c|c|c|c|c|c|c|c|}
\hline $\begin{array}{l}\text { 1. л. ед. } \\
\text { ч. сег. вр. }\end{array}$ & $\begin{array}{l}\text { 3. л. ед. ч. } \\
\text { сег. вр. }\end{array}$ & $\begin{array}{l}\text { 1. л. мн.ч. } \\
\text { сег. вр. }\end{array}$ & $\begin{array}{l}1 \text { л. ед. ч. } \\
\text { мин. св. } \\
\text { време }\end{array}$ & $\begin{array}{l}1 \text { л. ед. ч. } \\
\text { мин. несв. } \\
\text { време }\end{array}$ & $\begin{array}{l}3 \text { л. ед. ч. } \\
\text { мин. несв. } \\
\text { време }\end{array}$ & $\begin{array}{l}\text { М. р. ед. ч. } \\
\text { с формант -л- от } \\
\text { аористна основа }\end{array}$ & $\begin{array}{l}\text { М. р. ед. ч. с фор- } \\
\text { мант -л- от импер- } \\
\text { фектна основа }\end{array}$ & $\begin{array}{l}\text { Мн. ч. с формант } \\
\text {-л- от имперфек- } \\
\text { тна основа }\end{array}$ & $\begin{array}{l}\text { М. р. ед. ч. } \\
\text { с формант } \\
\text {-н/-т- }\end{array}$ & $\begin{array}{l}\text { М. р. ед. ч. } \\
\text { с формант } \\
\text {-щ- }\end{array}$ & $\begin{array}{l}\text { Форми с импера- } \\
\text { тивен формант }\end{array}$ \\
\hline $\begin{array}{l}-\varnothing-\mathrm{a} \\
\text { лъж-Ø-а }\end{array}$ & $\begin{array}{l}\text { е- } \\
\text { лъж-е- } \varnothing\end{array}$ & $\begin{array}{l}\text {-е-м } \\
\text { лъж-е-м }\end{array}$ & $\begin{array}{l}-a-x-\varnothing \\
\text { лъг-a-x- } \varnothing\end{array}$ & $\begin{array}{l}\text {-е-х-Ø } \\
\text { лъж-е-х- } \varnothing\end{array}$ & $\begin{array}{l}\text {-е-ш-е } \\
\text { лъж-е-ш-е }\end{array}$ & $\begin{array}{l}\text {-а-л- } \varnothing \\
\text { лъг-а-л- } \varnothing\end{array}$ & $\begin{array}{l}\text {-е-л-Ø } \\
\text { лъж-е-л-Ø }\end{array}$ & $\begin{array}{l}\text {-е-л-и } \\
\text { лъж-е-л-и }\end{array}$ & $\begin{array}{l}\text {-а-н- } \varnothing \\
\text { лъг-а-н- } \varnothing\end{array}$ & $\begin{array}{l}\text {-е-щ- } \\
\text { лъж-е- } \\
\text { щ- }\end{array}$ & $\begin{array}{l}\text {-Ø-ѝ- }, \\
\text {-Ø-ѐ-те } \\
\text { лъж-Ø-й-Ø } \\
\text { лъж-Ø-ѐ-те }\end{array}$ \\
\hline
\end{tabular}

\section{ТИП 12 - обособява се от ТИП 11 поради липса на форми с формант -щ-: ИЗЛЪЖА}

\begin{tabular}{|c|c|c|c|c|c|c|c|c|c|c|c|}
\hline $\begin{array}{l}\text { 1. л. ед. } \\
\text { ч. сег. вр. }\end{array}$ & $\begin{array}{l}\text { 3. л. ед. ч. } \\
\text { сег. вр. }\end{array}$ & $\begin{array}{l}\text { 1. л. мн.ч. } \\
\text { сег. вр. }\end{array}$ & $\begin{array}{l}1 \text { л. ед. ч. } \\
\text { мин. св. } \\
\text { време }\end{array}$ & $\begin{array}{l}1 \text { л. ед. ч. } \\
\text { мин. несв. } \\
\text { време }\end{array}$ & $\begin{array}{l}3 \text { л. ед. ч. } \\
\text { мин. несв. } \\
\text { време }\end{array}$ & $\begin{array}{l}\text { М. р. ед. ч. } \\
\text { с формант -л- от } \\
\text { аористна основа }\end{array}$ & $\begin{array}{l}\text { М. р. ед. ч. с фор- } \\
\text { мант-Л- от импер- } \\
\text { фектна основа }\end{array}$ & $\begin{array}{l}\text { Мн. ч. с формант } \\
\text {-л- от имперфек- } \\
\text { тна основа }\end{array}$ & $\begin{array}{l}\text { М. р. ед. ч. } \\
\text { с формант } \\
\text {-н/-т- }\end{array}$ & $\begin{array}{l}\text { М. р. ед. ч. } \\
\text { с формант } \\
\text {-щ- }\end{array}$ & $\begin{array}{l}\text { Форми с импера- } \\
\text { тивен формант }\end{array}$ \\
\hline $\begin{array}{l}-\varnothing-\mathrm{a} \\
\text { излъ- } \\
\text { ж-Ø-а }\end{array}$ & $\begin{array}{l}\text { e- } \\
\text { излъ- } \\
\text { ж-е- } \varnothing\end{array}$ & $\begin{array}{l}\text {-е-м } \\
\text { излъж-е-м }\end{array}$ & $\begin{array}{l}-\mathrm{a}-\mathrm{x}-\varnothing \\
\text { излъг-а- } \\
\mathrm{x- \varnothing}\end{array}$ & $\begin{array}{l}\text {-е-х- } ~ \\
\text { излъж-е- } \\
\text { х- }\end{array}$ & $\begin{array}{l}\text {-е-ш-е } \\
\text { излъж-е- } \\
\text { ш-е }\end{array}$ & $\begin{array}{l}\text {-а-л- } \varnothing \\
\text { излъгг-а-л- }\end{array}$ & $\begin{array}{l}\text {-е-л- } \varnothing \\
\text { излъж-е-л-Ø }\end{array}$ & $\begin{array}{l}\text {-е-л-и } \\
\text { излъж-е-л-и }\end{array}$ & $\begin{array}{l}-\mathrm{a}-\mathrm{H}-\varnothing \\
\text { излъг-а- } \\
\text { н- } \varnothing\end{array}$ & - & $\begin{array}{l}\text {-Ø-ѝ- } \varnothing, \\
\text {-Ø-ѐ-те } \\
\text { излъж- } \varnothing \text {-й- } \\
\text { излъж-Ø-ѐ-те }\end{array}$ \\
\hline
\end{tabular}

\section{ТИП 13 - обособява се от ТИП 12 поради липса на форми с формант -н-/-m-: САМОЗАЛЪЖА СЕ}

\begin{tabular}{|c|c|c|c|c|c|c|c|c|c|c|c|}
\hline $\begin{array}{l}\text { 1. л. ед. } \\
\text { ч. сег. вр. }\end{array}$ & $\begin{array}{l}\text { 3. л. ед. ч. } \\
\text { сег. вр. }\end{array}$ & $\begin{array}{l}\text { 1. л. мн.ч. } \\
\text { сег. вр. }\end{array}$ & $\begin{array}{l}1 \text { л. ед. ч. } \\
\text { мин. св. } \\
\text { време }\end{array}$ & $\begin{array}{l}1 \text { л. ед. ч. } \\
\text { мин. несв. } \\
\text { време }\end{array}$ & $\begin{array}{l}3 \text { л. ед. ч. } \\
\text { мин. несв. } \\
\text { време }\end{array}$ & $\begin{array}{l}\text { М. р. ед. ч. } \\
\text { с формант -л- от } \\
\text { аористна основа }\end{array}$ & $\begin{array}{l}\text { М. р. ед. ч. с фор- } \\
\text { мант-л- от импер- } \\
\text { фектна основа }\end{array}$ & $\begin{array}{l}\text { Мн. ч. с формант } \\
\text {-л- от имперфек- } \\
\text { тна основа }\end{array}$ & $\begin{array}{l}\text { М. р. ед. ч. } \\
\text { с формант } \\
\text {-н/-т- }\end{array}$ & $\begin{array}{l}\text { М.р. ед. ч. } \\
\text { с формант } \\
\text {-щ- }\end{array}$ & $\begin{array}{l}\text { Форми с императи- } \\
\text { вен формант }\end{array}$ \\
\hline $\begin{array}{l}-\varnothing \text {-а } \\
\text { самозалъ- } \\
\text { ж-Ø-а се }\end{array}$ & $\begin{array}{l}\text { e- } \varnothing \\
\text { само- } \\
\text { залъ- } \\
\text { ж-е- Øсе }\end{array}$ & $\begin{array}{l}\text {-е-м } \\
\text { само- } \\
\text { залъ- } \\
\text { ж-е-м се }\end{array}$ & $\begin{array}{l}\text {-а-х- } \varnothing \\
\text { само- } \\
\text { залъг-а- } \\
\text { х-Øсе }\end{array}$ & $\begin{array}{l}\text {-е-х- } \\
\text { самозалъ- } \\
\text { ж-е-х-Ø се }\end{array}$ & $\begin{array}{l}\text {-е-ш-е } \\
\text { самозалъ- } \\
\text { ж-е-ш-е се }\end{array}$ & $\begin{array}{l}\text {-а-л- } \varnothing \\
\text { самозальг-а-л- } \varnothing \text { се }\end{array}$ & $\begin{array}{l}\text {-е-л- } \\
\text { самозалъж-е-л- } \varnothing \\
\text { се }\end{array}$ & $\begin{array}{l}\text {-е-л-и } \\
\text { самозалъж-е-л-и се }\end{array}$ & - & - & $\begin{array}{l}\text {-Ø-ѝ- }, \\
\text {-Ø-ѐ-те } \\
\text { самолъж- } \emptyset \text {-ѝ- } \emptyset \text { се } \\
\text { самозалъж-Ø-ѐ-те се }\end{array}$ \\
\hline
\end{tabular}


ТИП 14 - обособява се от ТИП 2 по наличие на редуване Ж $\rightarrow 3$ в корена на формите, образувани от аористната основа: МАЖА

\begin{tabular}{|c|c|c|c|c|c|c|c|c|c|c|c|}
\hline $\begin{array}{l}\text { 1. л. ед. } \\
\text { ч. сег. вр. }\end{array}$ & $\begin{array}{l}\text { 3. л. ед. ч. } \\
\text { сег. вр. }\end{array}$ & $\begin{array}{l}\text { 1. л. мн.ч. } \\
\text { сег. вр. }\end{array}$ & $\begin{array}{l}1 \text { л. ед. ч. } \\
\text { мин. св. } \\
\text { време }\end{array}$ & $\begin{array}{l}1 \text { л. ед. ч. } \\
\text { мин. несв. } \\
\text { време }\end{array}$ & $\begin{array}{l}3 \text { л. ед. ч. } \\
\text { мин. несв. } \\
\text { време }\end{array}$ & $\begin{array}{l}\text { М. р. ед. ч. } \\
\text { с формант -л- от } \\
\text { аористна основа }\end{array}$ & $\begin{array}{l}\text { М. р. ед. ч. с фор- } \\
\text { мант -л- от импер- } \\
\text { фектна основа }\end{array}$ & $\begin{array}{l}\text { Мн. ч. с формант } \\
\text {-л- от имперфек- } \\
\text { тна основа }\end{array}$ & $\begin{array}{l}\text { М. р. ед. ч. } \\
\text { с формант } \\
\text {-н/-т- }\end{array}$ & $\begin{array}{l}\text { М. р. ед. ч. } \\
\text { с формант } \\
\text {-щ- }\end{array}$ & $\begin{array}{l}\text { Форми с импера- } \\
\text { тивен формант }\end{array}$ \\
\hline $\begin{array}{l}-\emptyset \text {-а } \\
\text { мàж-Ø-a }\end{array}$ & $\begin{array}{l}\text {-e-м } \\
\text { ма̀ж-е-м }\end{array}$ & $\begin{array}{l}\text {-a-x-Ø } \\
\text { мà3-a-x-Ø }\end{array}$ & $\begin{array}{l}\text {-a-Ø-Ø } \\
\text { мà3-a- } \varnothing-\varnothing\end{array}$ & $\begin{array}{l}\text {-e-x- } \varnothing \\
\text { ма̀ж-e-x-Ø }\end{array}$ & $\begin{array}{l}\text {-е-ш-е } \\
\text { ма̀ж-е-ш-е }\end{array}$ & $\begin{array}{l}\text {-а-л-Ø } \\
\text { мà3-а-л- } \varnothing\end{array}$ & $\begin{array}{l}\text {-е-л- } \emptyset \\
\text { ма̀ж-е-л-Ø }\end{array}$ & $\begin{array}{l}\text {-е-л-и } \\
\text { ма̀ж-е-л-и }\end{array}$ & $\begin{array}{l}\text {-а-н- } \varnothing \\
\text { мà3-a-н-Ø }\end{array}$ & $\begin{array}{l}\text {-е-щ-Ø } \\
\text { ма̀ж-е- } \\
\text { щ- }\end{array}$ & $\begin{array}{l}\text {-Ø-й- } \varnothing, \\
\text {-Ø-ѐ-те } \\
\text { маж- Ø-й-Ø } \\
\text { маж-Ø-ѐ-те }\end{array}$ \\
\hline
\end{tabular}

ТИП 15 - обособява се от ТИП 14 по липса на форми с формант -щ-: СМАЖА

\begin{tabular}{|c|c|c|c|c|c|c|c|c|c|c|c|}
\hline $\begin{array}{l}\text { 1. л. ед. } \\
\text { ч. сег. вр. }\end{array}$ & $\begin{array}{l}\text { 3. л. ед. ч. } \\
\text { сег. вр. }\end{array}$ & $\begin{array}{l}\text { 1. л. мн.ч. } \\
\text { сег. вр. }\end{array}$ & $\begin{array}{l}1 \text { л. ед. ч. } \\
\text { мин. св. } \\
\text { време }\end{array}$ & $\begin{array}{l}1 \text { л. ед. ч. } \\
\text { мин. несв. } \\
\text { време }\end{array}$ & $\begin{array}{l}3 \text { л. ед. ч. } \\
\text { мин. несв. } \\
\text { време }\end{array}$ & $\begin{array}{l}\text { М.р. ед. ч. } \\
\text { с формант -л- от } \\
\text { аористна основа }\end{array}$ & $\begin{array}{l}\text { М. р. ед. ч. с фор- } \\
\text { мант -л- от импер- } \\
\text { фектна основа }\end{array}$ & $\begin{array}{l}\text { Мн. ч. с формант } \\
\text {-л- от имперфек- } \\
\text { тна основа }\end{array}$ & $\begin{array}{l}\text { М. р. ед. ч. } \\
\text { с формант } \\
\text {-н/-т- }\end{array}$ & $\begin{array}{l}\text { М. р. ед. ч. } \\
\text { с формант } \\
\text {-щ- }\end{array}$ & $\begin{array}{l}\text { Форми с импера- } \\
\text { тивен формант }\end{array}$ \\
\hline $\begin{array}{l}\text {-Ø-а } \\
\text { сма̀ж-Ø-a }\end{array}$ & $\begin{array}{l}\text {-е- } \\
\text { сма̀ж-е-Ø }\end{array}$ & $\begin{array}{l}\text {-e-м } \\
\text { сма̀ж-e-м }\end{array}$ & $\begin{array}{l}\text {-a-x- } \varnothing \\
\text { cмà3-a-x- } \varnothing\end{array}$ & $\begin{array}{l}\text {-e-x- } \varnothing \\
\text { сма̀ж-e- } \\
\text { x-Ø }\end{array}$ & $\begin{array}{l}\text {-е-ш-е } \\
\text { сма̀ж-е- } \\
\text { ш-е }\end{array}$ & $\begin{array}{l}\text {-а-л- } \varnothing \\
\text { сма̀з-а-л- } \varnothing\end{array}$ & $\begin{array}{l}\text {-е-л- } \varnothing \\
\text { сма̀ж-е-л-Ø }\end{array}$ & $\begin{array}{l}\text {-е-л-и } \\
\text { сма̀ж-е-л-и }\end{array}$ & $\begin{array}{l}\text {-a-H- } \varnothing \\
\text { cмà3-a- } \\
\text { H-Ø }\end{array}$ & - & $\begin{array}{l}\text {-Ø-ѝ- } \varnothing, \\
\text {-Ø-ѐ-те } \\
\text { смаж-Ø-ѝ-Ø } \\
\text { смаж-Ø-ѐ-те }\end{array}$ \\
\hline
\end{tabular}

ТИП 16 - обособява се от ТИП 2 по наличие на редуване Ч $\rightarrow$ в корена на формите, образувани от аористната основа: ДЬВЧА

\begin{tabular}{|c|c|c|c|c|c|c|c|c|c|c|c|}
\hline $\begin{array}{l}\text { 1. л. ед. } \\
\text { ч. сег. вр. }\end{array}$ & $\begin{array}{l}\text { 3. л. ед. ч. } \\
\text { сег. вр. }\end{array}$ & $\begin{array}{l}\text { 1. л. мн.ч. } \\
\text { сег. вр. }\end{array}$ & $\begin{array}{l}1 \text { л. ед. ч. } \\
\text { мин. св. } \\
\text { време }\end{array}$ & $\begin{array}{l}1 \text { л. ед. ч. } \\
\text { мин. несв. } \\
\text { време }\end{array}$ & $\begin{array}{l}3 \text { л. ед. ч. } \\
\text { мин. несв. } \\
\text { време }\end{array}$ & $\begin{array}{l}\text { М.р. ед. ч. } \\
\text { с формант -л- от } \\
\text { аористна основа }\end{array}$ & $\begin{array}{l}\text { М. р. ед. ч. с фор- } \\
\text { мант -л- от импер- } \\
\text { фектна основа }\end{array}$ & $\begin{array}{l}\text { Мн. ч. с формант } \\
\text {-л- от имперфек- } \\
\text { тна основа }\end{array}$ & $\begin{array}{l}\text { М. р. ед. ч. } \\
\text { с формант } \\
\text {-н/-т- }\end{array}$ & $\begin{array}{l}\text { М. р. ед. ч. } \\
\text { с формант } \\
\text {-щ- }\end{array}$ & $\begin{array}{l}\text { Форми с импера- } \\
\text { тивен формант }\end{array}$ \\
\hline $\begin{array}{l}-\varnothing-\mathrm{a} \\
\text { ДъВч-Ø-а }\end{array}$ & $\begin{array}{l}\text {-е- } \varnothing \\
\text { дъвч-е- } \varnothing\end{array}$ & $\begin{array}{l}\text {-е-м } \\
\text { дъвч-е-м }\end{array}$ & $\begin{array}{l}-a-x-\varnothing \\
\text { дъвк-а- } \\
x-\varnothing\end{array}$ & $\begin{array}{l}-e-x-\varnothing \\
\text { дъвч-е- } \\
x-\varnothing\end{array}$ & $\begin{array}{l}\text {-е-ш-е } \\
\text { дъвч-e- } \\
ш-е\end{array}$ & $\begin{array}{l}\text {-а-л-Ø } \\
\text { дъвк-а-л-Ø }\end{array}$ & $\begin{array}{l}\text {-е-л-Ø } \\
\text { дъвч-е-л- } \varnothing\end{array}$ & $\begin{array}{l}\text {-е-л-и } \\
\text { дъвч-е-л-и }\end{array}$ & $\begin{array}{l}-\mathrm{a}-\mathrm{H}-\varnothing \\
\text { дъвк-а- } \\
\mathrm{H-} \varnothing\end{array}$ & $\begin{array}{l}\text {-е-щ- } \varnothing \\
\text { дъвч-е- } \\
\text { щ- }\end{array}$ & $\begin{array}{l}\text {-Ø-ѝ-Ø, } \\
\text {-Ø-ѐ-те } \\
\text { дъвч-Ø-ѝ-Ø } \\
\text { дъвч-Ø-ѐ-те }\end{array}$ \\
\hline
\end{tabular}


ТИП 17 - обособява се от ТИП 16 поради липса на форма с формант -н-/-m-: ПЛАЧА

\begin{tabular}{|c|c|c|c|c|c|c|c|c|c|c|c|}
\hline $\begin{array}{l}\text { 1. л. ед. } \\
\text { ч. сег. вр. }\end{array}$ & $\begin{array}{l}\text { 3. л. ед. ч. } \\
\text { сег. вр. }\end{array}$ & $\begin{array}{l}\text { 1. л. мн.ч. } \\
\text { сег. вр. }\end{array}$ & $\begin{array}{l}1 \text { л. ед. ч. } \\
\text { мин. св. } \\
\text { време }\end{array}$ & $\begin{array}{l}1 \text { л. ед. ч. } \\
\text { мин. несв. } \\
\text { време }\end{array}$ & $\begin{array}{l}3 \text { л. ед. ч. } \\
\text { мин. несв. } \\
\text { време }\end{array}$ & $\begin{array}{l}\text { М. р. ед. ч. } \\
\text { с формант -л- от } \\
\text { аористна основа }\end{array}$ & $\begin{array}{l}\text { М. р. ед. ч. с фор- } \\
\text { мант } \\
\text {-л- от имперфек- } \\
\text { тна основа }\end{array}$ & $\begin{array}{l}\text { Мн. ч. с формант } \\
\text {-л- от имперфек- } \\
\text { тна основа }\end{array}$ & $\begin{array}{l}\text { М. р. ед. ч. } \\
\text { с формант } \\
\text {-н/-т- }\end{array}$ & $\begin{array}{l}\text { М. р. ед. ч. } \\
\text { с формант } \\
\text {-щ- }\end{array}$ & $\begin{array}{l}\text { Форми с импера- } \\
\text { тивен формант }\end{array}$ \\
\hline $\begin{array}{l}-\varnothing-\mathrm{a} \\
\text { плач- } \varnothing-\mathrm{a}\end{array}$ & $\begin{array}{l}\text {-е-Ø } \\
\text { плач-е-Ø }\end{array}$ & $\begin{array}{l}\text {-е-м } \\
\text { плач-е-м }\end{array}$ & $\begin{array}{l}-a-x-\varnothing \\
\text { плак-а- } \\
\text { x-Ø }\end{array}$ & $\begin{array}{l}-e-x-\varnothing \\
\text { плач-e- } \\
x-\varnothing\end{array}$ & $\begin{array}{l}\text {-е-ш-е } \\
\text { плач-е- } \\
\text { ш-е }\end{array}$ & $\begin{array}{l}\text {-а-л-Ø } \\
\text { плак-а-л-Ø }\end{array}$ & $\begin{array}{l}\text {-е-л-Ø } \\
\text { плач-е-л-Ø }\end{array}$ & $\begin{array}{l}\text {-е-л-и } \\
\text { плач-е-л-и }\end{array}$ & - & $\begin{array}{l}\text {-е-щ- } \varnothing \\
\text { плач-е- } \\
\text { щ-Ø }\end{array}$ & $\begin{array}{l}\text {-Ø-ѝ-Ø, } \\
\text {-Ø-ѐ-те } \\
\text { плач-Ø-й-Ø } \\
\text { плач-Ø-ѐ-те }\end{array}$ \\
\hline
\end{tabular}

ТИП 18 - обособява се от ТИП 16 по пипса на форма с формант -щ-: СДЪВЧА

\begin{tabular}{|c|c|c|c|c|c|c|c|c|c|c|c|}
\hline $\begin{array}{l}\text { 1. л. ед. } \\
\text { ч. сег. вр. }\end{array}$ & $\begin{array}{l}\text { 3. л. ед. ч. } \\
\text { сег. вр. }\end{array}$ & $\begin{array}{l}\text { 1. л. мн.ч. } \\
\text { сег. вр. }\end{array}$ & $\begin{array}{l}1 \text { л. ед. ч. } \\
\text { мин. св. } \\
\text { време }\end{array}$ & $\begin{array}{l}1 \text { л. ед. ч. } \\
\text { мин. несв. } \\
\text { време }\end{array}$ & $\begin{array}{l}3 \text { л. ед. ч. } \\
\text { мин. несв. } \\
\text { време }\end{array}$ & $\begin{array}{l}\text { М. р. ед. ч. } \\
\text { с формант -л- от } \\
\text { аористна основа }\end{array}$ & $\begin{array}{l}\text { М. р. ед. ч. с фор- } \\
\text { мант } \\
\text {-л- от имперфек- } \\
\text { тна основа }\end{array}$ & $\begin{array}{l}\text { Мн. ч. с формант } \\
\text {-л- от имперфек- } \\
\text { тна основа }\end{array}$ & $\begin{array}{l}\text { М. р. ед. ч. } \\
\text { с формант } \\
\text {-н/-т- }\end{array}$ & $\begin{array}{l}\text { М. р. ед. ч. } \\
\text { с формант } \\
\text {-щ- }\end{array}$ & $\begin{array}{l}\text { Форми с импера- } \\
\text { тивен формант }\end{array}$ \\
\hline $\begin{array}{l}-\varnothing \text {-а } \\
\text { сдъвч- } \varnothing-а\end{array}$ & $\begin{array}{l}\text {-е-Ø } \\
\text { сдъвч-е- } \varnothing\end{array}$ & $\begin{array}{l}-\mathrm{e}-\mathrm{M} \\
\text { сдъвч-е-м }\end{array}$ & $\begin{array}{l}\text {-a-x- } \varnothing \\
\text { сдъBК-a- } \\
\text { x- } \varnothing\end{array}$ & $\begin{array}{l}\text {-е-х- } \varnothing \\
\text { сдъвч-е- } \\
\text { х- } \varnothing\end{array}$ & $\begin{array}{l}\text {-е-ш-е } \\
\text { сдъвч-е- } \\
\text { ш-е }\end{array}$ & $\begin{array}{l}\text {-а-л- } \varnothing \\
\text { сдъвк-а-л- } \varnothing\end{array}$ & $\begin{array}{l}\text {-е-л- } \varnothing \\
\text { сдъвч-е-л- } \varnothing\end{array}$ & $\begin{array}{l}\text {-е-л-и } \\
\text { сдъвч-е-л-и }\end{array}$ & $\begin{array}{l}-\mathrm{a}-\mathrm{H}-\varnothing \\
\text { сдъвК-а- } \\
\text { н- } \varnothing\end{array}$ & - & $\begin{array}{l}\text {-Ø-ѝ- } \varnothing, \\
\text {-Ø-ѐ-те } \\
\text { сдъвч- } \emptyset \text {-ѝ-Ø } \\
\text { сдъвч-Ø-ѐ-те }\end{array}$ \\
\hline
\end{tabular}

ТИП 19 - обособява се от ТИП 2 по наличие на редуване Ш $\rightarrow$ В в корена на формите, образувани от аористната основа: ПИША

\begin{tabular}{|c|c|c|c|c|c|c|c|c|c|c|c|}
\hline $\begin{array}{l}\text { 1. л. ед. } \\
\text { ч. сег. вр. }\end{array}$ & $\begin{array}{l}\text { 3. л. ед. ч. } \\
\text { сег. вр. }\end{array}$ & $\begin{array}{l}\text { 1. л. мн.ч. } \\
\text { сег. вр. }\end{array}$ & $\begin{array}{l}1 \text { л. ед. ч. } \\
\text { мин. св. } \\
\text { време }\end{array}$ & $\begin{array}{l}1 \text { л. ед. ч. } \\
\text { мин. несв. } \\
\text { време }\end{array}$ & $\begin{array}{l}3 \text { л. ед. ч. } \\
\text { мин. несв. } \\
\text { време }\end{array}$ & $\begin{array}{l}\text { М.р. ед. ч. } \\
\text { с формант -л- от } \\
\text { аористна основа }\end{array}$ & $\begin{array}{l}\text { М. р. ед. ч. с фор- } \\
\text { мант } \\
\text {-л- от имперфек- } \\
\text { тна основа }\end{array}$ & $\begin{array}{l}\text { Мн. ч. с формант } \\
\text {-л- от имперфек- } \\
\text { тна основа }\end{array}$ & $\begin{array}{l}\text { М. р. ед. ч. } \\
\text { с формант } \\
\text {-н/-т- }\end{array}$ & $\begin{array}{l}\text { М. р. ед. ч. } \\
\text { с формант } \\
\text {-щ- }\end{array}$ & $\begin{array}{l}\text { Форми с импера- } \\
\text { тивен формант }\end{array}$ \\
\hline $\begin{array}{l}-\varnothing-\mathrm{a} \\
\text { пиш-Ø-а }\end{array}$ & $\begin{array}{l}\text {-е-Ø } \\
\text { пиш-е- } \varnothing\end{array}$ & $\begin{array}{l}\text {-е-м } \\
\text { пиш-е-м }\end{array}$ & $\begin{array}{l}\text {-а-х-Ø } \\
\text { пис-а-х-Ø }\end{array}$ & $\begin{array}{l}\text {-e-x- } \varnothing \\
\text { пиш-е-х-Ø }\end{array}$ & $\begin{array}{l}\text {-е-ш-е } \\
\text { пиш-е-ш-е }\end{array}$ & $\begin{array}{l}\text {-а-л-Ø } \\
\text { пис-а-л-Ø }\end{array}$ & $\begin{array}{l}\text {-е-л-Ø } \\
\text { пиш-е-л-Ø }\end{array}$ & $\begin{array}{l}\text {-е-л-и } \\
\text { пиш-е-л-и }\end{array}$ & $\begin{array}{l}\text {-а-н- } \varnothing \\
\text { пис-а-н- } \varnothing\end{array}$ & $\begin{array}{l}\text {-е-щ-Ø } \\
\text { пиш-е- } \\
\text { щ- }\end{array}$ & $\begin{array}{l}\text {-Ø-ѝ-Ø, } \\
\text {-Ø-ѐ-те } \\
\text { пиш-Ø-й-Ø } \\
\text { пиш-Ø-ѐ-те }\end{array}$ \\
\hline
\end{tabular}


ТИП 20 - обособява се от ТИП 19 поради липса на форма с формант -щ-: ЗАПИША

\begin{tabular}{|c|c|c|c|c|c|c|c|c|c|c|c|}
\hline $\begin{array}{l}\text { 1. л. ед. } \\
\text { ч. сег. вр. }\end{array}$ & $\begin{array}{l}\text { 3. л. ед. ч. } \\
\text { сег. вр. }\end{array}$ & $\begin{array}{l}\text { 1. л. мн.ч. } \\
\text { сег. вр. }\end{array}$ & $\begin{array}{l}1 \text { л. ед. ч. } \\
\text { мин. св. } \\
\text { време }\end{array}$ & $\begin{array}{l}1 \text { л. ед. ч. } \\
\text { мин. несв. } \\
\text { време }\end{array}$ & $\begin{array}{l}3 \text { л.ед. ч. } \\
\text { мин. несв. } \\
\text { време }\end{array}$ & $\begin{array}{l}\text { М. р. ед. ч. } \\
\text { с формант -л- от } \\
\text { аористна основа }\end{array}$ & $\begin{array}{l}\text { М. р. ед. ч. с фор- } \\
\text { мант -л- от импер- } \\
\text { фектна основа }\end{array}$ & $\begin{array}{l}\text { Мн. ч. с формант } \\
\text {-л- от имперфек- } \\
\text { тна основа }\end{array}$ & $\begin{array}{l}\text { М. р. ед. ч. } \\
\text { с формант } \\
\text {-н/-т- }\end{array}$ & $\begin{array}{l}\text { М. р. ед. ч. } \\
\text { с формант } \\
\text {-щ- }\end{array}$ & $\begin{array}{l}\text { Форми с импера- } \\
\text { тивен формант }\end{array}$ \\
\hline $\begin{array}{l}-\varnothing-\mathrm{a} \\
\text { запиш- } \\
\varnothing-\mathrm{a}\end{array}$ & $\begin{array}{l}\text {-e-Ø } \\
\text { запиш- } \\
\text { е-Ø }\end{array}$ & $\begin{array}{l}-е-м \\
\text { запиш-е-м }\end{array}$ & $\begin{array}{l}-a-x-\varnothing \\
\text { запис-а- } \\
x-\varnothing\end{array}$ & $\begin{array}{l}\text {-е-х- } \varnothing \\
\text { запиш-е- } \\
\text { х-Ø }\end{array}$ & $\begin{array}{l}\text {-е-ш-е } \\
\text { запиш-е- } \\
\text { ш-е }\end{array}$ & $\begin{array}{l}\text {-а-л- } \varnothing \\
\text { запис-а-л- }\end{array}$ & $\begin{array}{l}\text {-е-л-Ø } \\
\text { запиш-е-л-Ø }\end{array}$ & $\begin{array}{l}\text {-е-л-и } \\
\text { запиш-е-л-и }\end{array}$ & $\begin{array}{l}-\mathrm{a}-\mathrm{H}-\varnothing \\
\text { запис-а- } \\
\text { н-Ø }\end{array}$ & - & 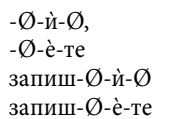 \\
\hline
\end{tabular}

\section{ТИП 21 - обособява се от ТИП 20 поради липса на форма с формант -н-/-m-: ЗАМИРИША}

\begin{tabular}{|c|c|c|c|c|c|c|c|c|c|c|c|}
\hline $\begin{array}{l}\text { 1. л. ед. } \\
\text { ч. сег. вр. }\end{array}$ & $\begin{array}{l}\text { 3. л. ед. ч. } \\
\text { сег. вр. }\end{array}$ & $\begin{array}{l}\text { 1. л. мн.ч. } \\
\text { сег. вр. }\end{array}$ & $\begin{array}{l}1 \text { л. ед. ч. } \\
\text { мин. св. } \\
\text { време }\end{array}$ & $\begin{array}{l}1 \text { л. ед. ч. } \\
\text { мин. несв. } \\
\text { време }\end{array}$ & $\begin{array}{l}3 \text { л. ед. ч. } \\
\text { мин. несв. } \\
\text { време }\end{array}$ & $\begin{array}{l}\text { М. p. ед. ч. } \\
\text { с формант -л- от } \\
\text { аористна основа }\end{array}$ & $\begin{array}{l}\text { М. р. ед. ч. с фор- } \\
\text { мант -л- от импер- } \\
\text { фектна основа }\end{array}$ & $\begin{array}{l}\text { Мн. ч. с формант } \\
\text {-л- от имперфек- } \\
\text { тна основа }\end{array}$ & $\begin{array}{l}\text { М. р. ед. ч. } \\
\text { с формант } \\
\text {-н/-т- }\end{array}$ & $\begin{array}{l}\text { М. р. ед. ч. } \\
\text { с формант } \\
\text {-щ- }\end{array}$ & $\begin{array}{l}\text { Форми с импера- } \\
\text { тивен формант }\end{array}$ \\
\hline $\begin{array}{l}-\varnothing-\mathrm{a} \\
\text { зами- } \\
\text { риш-Ø-а }\end{array}$ & $\begin{array}{l}\text {-е-Ø } \\
\text { зами- } \\
\text { риш-е-Ø }\end{array}$ & $\begin{array}{l}\text {-е-м } \\
\text { замириш } \\
\text {-е-м }\end{array}$ & $\begin{array}{l}-a-x-\varnothing \\
\text { замирис } \\
-a-x-\varnothing\end{array}$ & $\begin{array}{l}\text {-е-х-Ø } \\
\text { замириш } \\
\text {-е-х-Ø }\end{array}$ & $\begin{array}{l}\text {-е-ш-е } \\
\text { замириш } \\
\text {-е-ш-е }\end{array}$ & $\begin{array}{l}\text {-а-л- } \emptyset \\
\text { замирис-а-л- } \varnothing\end{array}$ & $\begin{array}{l}\text {-е-л-Ø } \\
\text { замириш -е-л-Ø }\end{array}$ & $\begin{array}{l}\text {-е-л-и } \\
\text { замириш -е-л-и }\end{array}$ & - & - & $\begin{array}{l}\text {-Ø-̀̀-Ø, } \\
\text {-Ø-ѐ-те } \\
\text { замириш-Ø-ѝ-Ø } \\
\text { замириш-Ø-ѐ-те }\end{array}$ \\
\hline
\end{tabular}

ТИП 22 - обособява се от ТИП 14 поради преглас Е $\rightarrow$ в корена на формите, образувани от аористната основа: РЕЖА

\begin{tabular}{|c|c|c|c|c|c|c|c|c|c|c|c|}
\hline $\begin{array}{l}\text { 1. л. ед. } \\
\text { ч. сег. вр. }\end{array}$ & $\begin{array}{l}\text { 3. л. ед. ч. } \\
\text { сег. вр. }\end{array}$ & $\begin{array}{l}\text { 1. л. мн.ч. } \\
\text { сег. вр. }\end{array}$ & $\begin{array}{l}1 \text { л. ед. ч. } \\
\text { мин. св. } \\
\text { време }\end{array}$ & $\begin{array}{l}1 \text { л. ед. ч. } \\
\text { мин. несв. } \\
\text { време }\end{array}$ & $\begin{array}{l}3 \text { л. ед. ч. } \\
\text { мин. несв. } \\
\text { време }\end{array}$ & $\begin{array}{l}\text { М. р. ед. ч. } \\
\text { с формант -л- от } \\
\text { аористна основа }\end{array}$ & $\begin{array}{l}\text { М. р. ед. ч. с фор- } \\
\text { мант -л- от импер- } \\
\text { фектна основа }\end{array}$ & $\begin{array}{l}\text { Мн. ч. с формант } \\
\text {-л- от имперфек- } \\
\text { тна основа }\end{array}$ & $\begin{array}{l}\text { М. р. ед. ч. } \\
\text { с формант } \\
\text {-н/-т- }\end{array}$ & $\begin{array}{l}\text { М. р. ед. ч. } \\
\text { с формант } \\
\text {-щ- }\end{array}$ & $\begin{array}{l}\text { Форми с импера- } \\
\text { тивен формант }\end{array}$ \\
\hline $\begin{array}{l}-\emptyset \text {-а } \\
\text { рѐж-Ø-а }\end{array}$ & $\begin{array}{l}\text {-е- } \varnothing \\
\text { рёж-е- } \varnothing\end{array}$ & $\begin{array}{l}\text {-е-м } \\
\text { рѐж-е-м }\end{array}$ & $\begin{array}{l}\text {-а-х- } \varnothing \\
\text { ряз-а-х- } \varnothing\end{array}$ & $\begin{array}{l}\text {-е-x-Ø } \\
\text { рѐж-е-x-Ø }\end{array}$ & $\begin{array}{l}\text {-е-ш-е } \\
\text { рѐж-е-ш-е }\end{array}$ & $\begin{array}{l}\text {-а-л-Ø } \\
\text { ряз-а-л- } \varnothing\end{array}$ & $\begin{array}{l}\text {-е-л-Ø } \\
\text { рѐж-е-л-Ø }\end{array}$ & $\begin{array}{l}\text {-е-л-и } \\
\text { рѐж-е-л-и }\end{array}$ & $\begin{array}{l}\text {-а-н- } \varnothing \\
\text { ряз-а-н- } \varnothing\end{array}$ & $\begin{array}{l}\text {-е-щ-Ø } \\
\text { рѐж-е- } \\
\text { щ- }\end{array}$ & 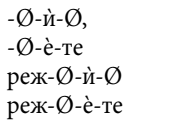 \\
\hline
\end{tabular}


ТИП 23 - обособява се от ТИП 22 поради липса на форми с формант -щ-: СРЕЖА

\begin{tabular}{|c|c|c|c|c|c|c|c|c|c|c|c|}
\hline $\begin{array}{l}\text { 1. л. ед. } \\
\text { ч. сег. вр. }\end{array}$ & $\begin{array}{l}\text { 3. л. ед. ч. } \\
\text { сег. вр. }\end{array}$ & $\begin{array}{l}\text { 1. л. мн.ч. } \\
\text { сег. вр. }\end{array}$ & $\begin{array}{l}1 \text { л. ед. ч. } \\
\text { мин. св. } \\
\text { време }\end{array}$ & $\begin{array}{l}1 \text { л. ед. ч. } \\
\text { мин. несв. } \\
\text { време }\end{array}$ & $\begin{array}{l}3 \text { л. ед. ч. } \\
\text { мин. несв. } \\
\text { време }\end{array}$ & $\begin{array}{l}\text { М. р. ед. ч. } \\
\text { с формант -л- от } \\
\text { аористна основа }\end{array}$ & $\begin{array}{l}\text { М. р. ед. ч. с фор- } \\
\text { мант } \\
\text {-л- от имперфек- } \\
\text { тна основа }\end{array}$ & $\begin{array}{l}\text { Мн. ч. с формант } \\
\text {-л- от имперфек- } \\
\text { тна основа }\end{array}$ & $\begin{array}{l}\text { М. р. ед. ч. } \\
\text { с формант } \\
\text {-н/-т- }\end{array}$ & $\begin{array}{l}\text { М. р. ед. ч. } \\
\text { с формант } \\
\text {-щ- }\end{array}$ & $\begin{array}{l}\text { Форми с импера- } \\
\text { тивен формант }\end{array}$ \\
\hline $\begin{array}{l}\text {-Ø-а } \\
\text { срѐж-Ø-а }\end{array}$ & $\begin{array}{l}\text {-е-Ø } \\
\text { срѐж-е-Ø }\end{array}$ & $\begin{array}{l}\text {-е-м } \\
\text { срѐж-е-м }\end{array}$ & $\begin{array}{l}-a-x-\varnothing \\
\text { сряз-а-x- } \varnothing\end{array}$ & $\begin{array}{l}\text {-е-х- } \varnothing \\
\text { срёж-е- } \\
\text { x- } \varnothing\end{array}$ & $\begin{array}{l}\text {-е-ш-е } \\
\text { срѐж-е- } \\
\text { ш-е }\end{array}$ & $\begin{array}{l}\text {-а-л- } \varnothing \\
\text { сряз-а-л- }\end{array}$ & $\begin{array}{l}\text {-е-л- } \varnothing \\
\text { срѐж-е-л- } \varnothing\end{array}$ & $\begin{array}{l}\text {-е-л-и } \\
\text { срѐж-е-л-и }\end{array}$ & $\begin{array}{l}\text {-a-н- } \varnothing \\
\text { сряз-а- } \\
\text { н-Ø }\end{array}$ & - & $\begin{array}{l}\text {-Ø-ѝ- } \emptyset, \\
\text {-Ø-ѐ-те } \\
\text { среж-Ø-ѝ- } \\
\text { среж-Ø-ѐ-те }\end{array}$ \\
\hline
\end{tabular}

ТИП 24 - обособява се от ТИП 3 поради липса на форми за аорист и на форми, образувани от аористна основа: ИДА

\begin{tabular}{|c|c|c|c|c|c|c|c|c|c|c|c|}
\hline $\begin{array}{l}\text { 1. л. ед. } \\
\text { ч. сег. вр. }\end{array}$ & $\begin{array}{l}\text { 3. л. ед. ч. } \\
\text { сег. вр. }\end{array}$ & $\begin{array}{l}\text { 1. л. мн.ч. } \\
\text { сег. вр. }\end{array}$ & $\begin{array}{l}1 \text { л. ед. ч. } \\
\text { мин. св. } \\
\text { време }\end{array}$ & $\begin{array}{l}1 \text { л. ед. ч. } \\
\text { мин. несв. } \\
\text { време }\end{array}$ & $\begin{array}{l}3 \text { л. ед. ч. } \\
\text { мин. несв. } \\
\text { време }\end{array}$ & $\begin{array}{l}\text { М.р. ед. ч. } \\
\text { с формант -л- от } \\
\text { аористна основа }\end{array}$ & $\begin{array}{l}\text { М. р. ед. ч. с фор- } \\
\text { мант } \\
\text {-л- от имперфек- } \\
\text { тна основа }\end{array}$ & $\begin{array}{l}\text { Мн. ч. с формант } \\
\text {-л- от имперфек- } \\
\text { тна основа }\end{array}$ & $\begin{array}{l}\text { М. р. ед. ч. } \\
\text { с формант } \\
\text {-Н/-т- }\end{array}$ & $\begin{array}{l}\text { М. р. ед. ч. } \\
\text { с формант } \\
\text {-щ- }\end{array}$ & $\begin{array}{l}\text { Форми с импера- } \\
\text { тивен формант }\end{array}$ \\
\hline $\begin{array}{l}-\varnothing-\mathrm{a} \\
\text { ѝд-Ø-а }\end{array}$ & $\begin{array}{l}\text {-е-Ø } \\
\text { йд-е-Ø }\end{array}$ & $\begin{array}{l}-\mathrm{e}-\mathrm{M} \\
\text { йд-е-м }\end{array}$ & - & $\begin{array}{l}\text {-е-х-Ø } \\
\text { йд-е-х-Ø }\end{array}$ & $\begin{array}{l}\text {-е-ш-е } \\
\text { йд-е-ш-е }\end{array}$ & - & $\begin{array}{l}\text {-е-л- } \varnothing \\
\text { йд-е-л- Ø }\end{array}$ & $\begin{array}{l}\text {-е-л-и } \\
\text { йд-е-л-и }\end{array}$ & - & $\begin{array}{l}\text {-е-щ-Ø } \\
\text { ид-е-щ-Ø }\end{array}$ & 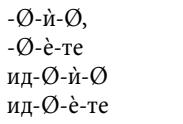 \\
\hline
\end{tabular}

ТИП 25 - обособява се от ТИП 24 по липса на форми с формант -щ-: ИДА

\begin{tabular}{|c|c|c|c|c|c|c|c|c|c|c|c|}
\hline $\begin{array}{l}\text { 1. л. ед. } \\
\text { ч. сег. вр. }\end{array}$ & $\begin{array}{l}\text { 3. л. ед. ч. } \\
\text { сег. вр. }\end{array}$ & $\begin{array}{l}\text { 1. л. мн.ч. } \\
\text { сег. вр. }\end{array}$ & $\begin{array}{l}1 \text { л. ед. ч. } \\
\text { мин. св. } \\
\text { време }\end{array}$ & $\begin{array}{l}1 \text { л. ед. ч. } \\
\text { мин. несв. } \\
\text { време }\end{array}$ & $\begin{array}{l}3 \text { л. ед. ч. } \\
\text { мин. несв. } \\
\text { време }\end{array}$ & $\begin{array}{l}\text { М. р. ед. ч. с фор- } \\
\text { мант -л- от аори- } \\
\text { стна основа }\end{array}$ & $\begin{array}{l}\text { М. р. ед. ч. с фор- } \\
\text { мант -л- от импер- } \\
\text { фектна основа }\end{array}$ & $\begin{array}{l}\text { Мн. ч. с формант } \\
\text {-л- от имперфек- } \\
\text { тна основа }\end{array}$ & $\begin{array}{l}\text { М. р. ед. ч. } \\
\text { с формант } \\
\text {-н/-т- }\end{array}$ & $\begin{array}{l}\text { М. р. ед. ч. } \\
\text { с формант } \\
\text {-щ- }\end{array}$ & $\begin{array}{l}\text { Форми с импера- } \\
\text { тивен формант }\end{array}$ \\
\hline $\begin{array}{l}-\emptyset-\mathrm{a} \\
\text { иेд-Ø-а }\end{array}$ & $\begin{array}{l}\text {-е- } \varnothing \\
\text { йд-е-Ø }\end{array}$ & $\begin{array}{l}\text {-е-м } \\
\text { йд-е-м }\end{array}$ & - & $\begin{array}{l}\text {-e-x- } \varnothing \\
\text { йд-е-х-Ø }\end{array}$ & $\begin{array}{l}\text {-е-ш-е } \\
\text { йд-е-ш-е }\end{array}$ & - & $\begin{array}{l}\text {-е-л-Ø } \\
\text { ид-е-л-Ø }\end{array}$ & $\begin{array}{l}\text {-е-л- } \\
\text { ид-е-л- }\end{array}$ & - & - & $\begin{array}{l}-\emptyset \text {-ѝ- }, \\
-\emptyset \text {-ѐ-те } \\
\text { ид-Ø-й-Ø } \\
\text { ид-Ø-ѐ-те }\end{array}$ \\
\hline
\end{tabular}


Към КЛАС 1 с комбинаторика -Е-Ø /-А-Х-Ø /-Е-Х-Ø от стойностите на презентна - аористна - импербектна тематична грамема се отнасят и глаголите от първо спрежение с корен на мека съгласна в основна форма и във формата за 3 л. мн. ч. сег. вр., отнасяни в Академичната граматика към III разред на I спрежение.

ТИП 26 - обособява се от ТИП 2 въз основа на редуването мекост/твърдост в корена на формите за 1 л. ед. и 3 л. мн. ч. сег. вр.: КЫПЯ

\begin{tabular}{|c|c|c|c|c|c|c|c|c|c|c|c|}
\hline $\begin{array}{l}\text { 1. л. ед. } \\
\text { ч. сег. вр. }\end{array}$ & $\begin{array}{l}\text { 3. л. ед. ч. } \\
\text { сег. вр. }\end{array}$ & $\begin{array}{l}\text { 1. л. мн.ч. } \\
\text { сег. вр. }\end{array}$ & $\begin{array}{l}1 \text { л. ед. ч. } \\
\text { мин. св. } \\
\text { време }\end{array}$ & $\begin{array}{l}1 \text { л. ед. ч. } \\
\text { мин. несв. } \\
\text { време }\end{array}$ & $\begin{array}{l}3 \text { л. ед. ч. } \\
\text { мин. несв. } \\
\text { време }\end{array}$ & $\begin{array}{l}\text { М. р. ед. ч. } \\
\text { с формант -л- от } \\
\text { аористна основа }\end{array}$ & $\begin{array}{l}\text { М. р. ед. ч. с фор- } \\
\text { мант } \\
\text {-л- от имперфек- } \\
\text { тна основа }\end{array}$ & $\begin{array}{l}\text { Мн. ч. с формант } \\
\text {-л- от имперфек- } \\
\text { тна основа }\end{array}$ & $\begin{array}{l}\text { М. р. ед. ч. } \\
\text { с формант } \\
\text {-н/-т- }\end{array}$ & $\begin{array}{l}\text { М. р. ед. ч. } \\
\text { с формант } \\
\text {-щ- }\end{array}$ & $\begin{array}{l}\text { Форми с импера- } \\
\text { тивен формант }\end{array}$ \\
\hline $\begin{array}{l}\therefore-\varnothing-\mathrm{a} \\
{[\text { къп'- }-\mathrm{a}]} \\
\text { къп-Ø-я }\end{array}$ & $\begin{array}{l}\text {-е- } \varnothing \\
\text { къп-е- } \varnothing\end{array}$ & $\begin{array}{l}\text {-е-м } \\
\text { къп-е-м }\end{array}$ & $\begin{array}{l}\text {-а-x-Ø } \\
\text { къп-а-х-Ø }\end{array}$ & $\begin{array}{l}\text {-е-х-Ø } \\
\text { къп-е-х-Ø }\end{array}$ & $\begin{array}{l}\text {-е-ш-е } \\
\text { къп-е-ш-е }\end{array}$ & $\begin{array}{l}\text {-а-л-Ø } \\
\text { къп-а-л-Ø }\end{array}$ & $\begin{array}{l}\text {-е-л-Ø } \\
\text { къп-е-л-Ø }\end{array}$ & $\begin{array}{l}\text {-е-л-и } \\
\text { къп-е-л-и }\end{array}$ & $\begin{array}{l}\text {-а-н- } \varnothing \\
\text { Къп-а-н- }\end{array}$ & $\begin{array}{l}\text {-е-щ- } \varnothing ~ \\
\text { къп-е- } \\
\text { щ-Ø }\end{array}$ & $\begin{array}{l}\text {-Ø-ѝ- } \varnothing, \\
\text {-Ø-ѐ-те } \\
\text { къп-Ø-ѝ- } \\
\text { къп-Ø-ѐ-те }\end{array}$ \\
\hline
\end{tabular}

ТИП 27 - Обособява се от ТИП 26 въз основа на липса на форми със стойности на форманта -н-/-m-: КАПЯ ДРЕМЯ

\begin{tabular}{|c|c|c|c|c|c|c|c|c|c|c|c|}
\hline $\begin{array}{l}\text { 1. л. ед. } \\
\text { ч. сег. вр. }\end{array}$ & $\begin{array}{l}\text { 3. л. ед. ч. } \\
\text { сег. вр. }\end{array}$ & $\begin{array}{l}\text { 1. л. мн.ч. } \\
\text { сег. вр. }\end{array}$ & $\begin{array}{l}1 \text { л. ед. ч. } \\
\text { мин. св. } \\
\text { време }\end{array}$ & $\begin{array}{l}1 \text { л. ед. ч. } \\
\text { мин. несв. } \\
\text { време }\end{array}$ & $\begin{array}{l}3 \text { л. ед. ч. } \\
\text { мин. несв. } \\
\text { време }\end{array}$ & $\begin{array}{l}\text { М. р. ед. ч. } \\
\text { с формант -л- от } \\
\text { аористна основа }\end{array}$ & $\begin{array}{l}\text { М. р. ед. ч. с фор- } \\
\text { мант } \\
\text {-л- от имперфек- } \\
\text { тна основа }\end{array}$ & $\begin{array}{l}\text { Мн. ч. с формант } \\
\text {-л- от имперфек- } \\
\text { тна основа }\end{array}$ & $\begin{array}{l}\text { М. р. ед. ч. } \\
\text { с формант } \\
\text {-н/-т- }\end{array}$ & $\begin{array}{l}\text { М.р. ед. ч. } \\
\text { с формант } \\
\text {-щ- }\end{array}$ & $\begin{array}{l}\text { Форми с импера- } \\
\text { тивен формант }\end{array}$ \\
\hline $\begin{array}{l}\therefore-\varnothing-\mathrm{a} \\
\text { [кап'-Ø-а] } \\
\text { кап-Ø-я }\end{array}$ & $\begin{array}{l}\text {-е-Ø } \\
\text { кап-е-Ø }\end{array}$ & $\begin{array}{l}-\mathrm{e}-\mathrm{m} \\
\text { кап-е-м }\end{array}$ & $\begin{array}{l}\text {-a-x-Ø } \\
\text { кап-а -x-Ø }\end{array}$ & $\begin{array}{l}\text {-е-х-Ø } \\
\text { кап-е-х-Ø }\end{array}$ & $\begin{array}{l}\text {-е-ш-е } \\
\text { кап-е-ш-е }\end{array}$ & $\begin{array}{l}\text {-а-л- } \varnothing \\
\text { кап-а-л-Ø }\end{array}$ & $\begin{array}{l}\text {-е-л- } \emptyset \\
\text { кап-е-л- } \varnothing\end{array}$ & $\begin{array}{l}\text {-е-л-и } \\
\text { кап-е-л-и }\end{array}$ & - & $\begin{array}{l}\text {-е-щ- } \varnothing \\
\text { кап-е-щ- }\end{array}$ & $\begin{array}{l}\text {-Ø-ѝ- } \varnothing, \\
\text {-Ø-ѐ-те } \\
\text { кап-Ø-ѝ-Ø } \\
\text { кап-Ø-ѐ-те }\end{array}$ \\
\hline
\end{tabular}


ТИП 28 - обособява се от ТИП 26 въз основа на липса на форма с формант -щ-: ИЗКЫПЯ

\begin{tabular}{|c|c|c|c|c|c|c|c|c|c|c|c|}
\hline $\begin{array}{l}\text { 1. л. ед. } \\
\text { ч. сег. вр. }\end{array}$ & $\begin{array}{l}\text { 3. л. ед. ч. } \\
\text { сег. вр. }\end{array}$ & $\begin{array}{l}\text { 1. л. мн.ч. } \\
\text { сег. вр. }\end{array}$ & $\begin{array}{l}1 \text { л. ед. ч. } \\
\text { мин. св. } \\
\text { време }\end{array}$ & $\begin{array}{l}1 \text { л. ед. ч. } \\
\text { мин. несв. } \\
\text { време }\end{array}$ & $\begin{array}{l}3 \text { л. ед. ч. } \\
\text { мин. несв. } \\
\text { време }\end{array}$ & $\begin{array}{l}\text { М. р. ед. ч. } \\
\text { с формант -л- от } \\
\text { аористна основа }\end{array}$ & $\begin{array}{l}\text { М. р. ед. ч. с фор- } \\
\text { мант -л- от импер- } \\
\text { фектна основа }\end{array}$ & $\begin{array}{l}\text { Мн. ч. с формант } \\
\text {-л- от имперфек- } \\
\text { тна основа }\end{array}$ & $\begin{array}{l}\text { М. р. ед. ч. } \\
\text { с формант } \\
\text {-н/-т- }\end{array}$ & $\begin{array}{l}\text { М. р. ед. ч. } \\
\text { с формант } \\
\text {-щ- }\end{array}$ & $\begin{array}{l}\text { Форми с импера- } \\
\text { тивен формант }\end{array}$ \\
\hline $\begin{array}{l}\therefore-\varnothing-\mathrm{a} \\
\text { [изкъп'- } \\
\varnothing-\mathrm{a}] \\
\text { изкъп-Ø-я }\end{array}$ & $\begin{array}{l}\text {-е-Ø } \\
\text { изкъп-е-Ø }\end{array}$ & $\begin{array}{l}\text {-е-м } \\
\text { изкъп-е-м }\end{array}$ & $\begin{array}{l}-a-x-\varnothing \\
\text { изкъп-а } \\
-x-\varnothing\end{array}$ & $\begin{array}{l}\text {-е-х- } \varnothing \\
\text { изкъп-е- } \\
\text { х- }\end{array}$ & $\begin{array}{l}\text {-е-ш-е } \\
\text { изкъп-е- } \\
\text { ш-е }\end{array}$ & $\begin{array}{l}\text {-а-л-Ø } \\
\text { изкъп-а-л-Ø }\end{array}$ & $\begin{array}{l}\text {-е-л-Ø } \\
\text { изкъп-е-л- } \varnothing\end{array}$ & $\begin{array}{l}\text {-е-л-и } \\
\text { изкъп-е-л-и }\end{array}$ & $\begin{array}{l}\text {-а-н- } \\
\text { изкъп-а- } \\
\text { н- }\end{array}$ & - & $\begin{array}{l}\text {-Ø-й- } \varnothing, \\
\text {-Ø-ѐ-те } \\
\text { изкъп-Ø-й-Ø } \\
\text { изкъп-Ø-ѐ-те }\end{array}$ \\
\hline
\end{tabular}

ТИП 29 - обособява се от ТИП 28 въз основа на наличието на форми само за 3 л. ед. и за мн. ч.: ИЗПОКАПЯ, ПОИЗКАПЯ

\begin{tabular}{|c|c|c|c|c|c|c|c|c|c|c|c|}
\hline $\begin{array}{l}\text { 1. л. ед. } \\
\text { ч. сег. вр. }\end{array}$ & $\begin{array}{l}\text { 3. л. ед. ч. } \\
\text { сег. вр. }\end{array}$ & $\begin{array}{l}\text { 1. л. мн.ч. } \\
\text { сег. вр. }\end{array}$ & $\begin{array}{l}1 \text { л. ед. ч. } \\
\text { мин. св. } \\
\text { време }\end{array}$ & $\begin{array}{l}1 \text { л. ед. ч. } \\
\text { мин. несв. } \\
\text { време }\end{array}$ & $\begin{array}{l}3 \text { л. ед. ч. } \\
\text { мин. несв. } \\
\text { време }\end{array}$ & $\begin{array}{l}\text { Мин. св. деят. } \\
\text { прич. }\end{array}$ & $\begin{array}{l}\text { Мин. нсв. деят. } \\
\text { прич. }\end{array}$ & & $-\mathrm{H} /-\mathrm{T}$ & -щ & $\begin{array}{l}\text { Форми с импера- } \\
\text { тивен формант }\end{array}$ \\
\hline - & $\begin{array}{l}\text {-е-Ø } \\
\text { изпока̀п- } \\
\text { e-Ø }\end{array}$ & $\begin{array}{l}\text {-е-м } \\
\text { изпока̀п- } \\
\text { е-м }\end{array}$ & - & - & $\begin{array}{l}\text {-е-ш-е } \\
\text { изпока̀п- } \\
\text { е-ш-е }\end{array}$ & $\begin{array}{l}\text {-a-л- } \varnothing \\
\text { изпока̀п-а-л- }\end{array}$ & $\begin{array}{l}\text {-е-л-Ø } \\
\text { изпока̀п-е-л- } \varnothing\end{array}$ & $\begin{array}{l}\text {-е-л-и } \\
\text { изпока̀п-е-л-и }\end{array}$ & $\begin{array}{l}\text {-а-н- } \varnothing \\
\text { изпокап- } \\
\text { а-н- } \varnothing\end{array}$ & - & $\begin{array}{l}\text {-Ø-ѝ-Ø, } \\
\text {-Ø-ѐ-те } \\
\text { изпокап-Ø-ѝ-Ø; } \\
\text { изпокап-Ø-ѐ-те }\end{array}$ \\
\hline
\end{tabular}

ТИП 30 - обособява се от ТИП 26 по наличие на дублетност във формите, образувани от аористната основа. При едната от дублетните форми е налице редуване $\mathrm{E} \rightarrow \varnothing$ с изпадане на кореновата гласна E; аористната основа без изпадане на кореновата гласна е с аористна тематична гласна -И-, свойствена на второ спрежение: ПОСТЕЛЯ

\begin{tabular}{|c|c|c|c|c|c|c|c|c|c|c|c|}
\hline $\begin{array}{l}\text { 1. л. ед. } \\
\text { ч. сег. вр. }\end{array}$ & $\begin{array}{l}\text { 3. л. ед. ч. } \\
\text { сег. вр. }\end{array}$ & $\begin{array}{l}\text { 1. л. мн.ч. } \\
\text { сег. вр. }\end{array}$ & $\begin{array}{l}1 \text { л. ед. ч. мин. } \\
\text { св. време }\end{array}$ & $\begin{array}{l}1 \text { л. ед. ч. } \\
\text { мин. несв. } \\
\text { време }\end{array}$ & $\begin{array}{l}3 \text { л. ед. ч. } \\
\text { мин. несв. } \\
\text { време }\end{array}$ & $\begin{array}{l}\text { М. р. ед. ч. с фор- } \\
\text { мант -л- от аористна } \\
\text { основа }\end{array}$ & $\begin{array}{l}\text { М. р. ед. ч. с фор- } \\
\text { мант -л- от импер- } \\
\text { фектна основа }\end{array}$ & $\begin{array}{l}\text { Мн. ч. с формант } \\
\text {-л- от имперфек- } \\
\text { тна основа }\end{array}$ & $\begin{array}{l}\text { М. р. ед. ч. } \\
\text { с формант } \\
\text {-н/-т- }\end{array}$ & $\begin{array}{l}\text { М. р. ед. ч. } \\
\text { с формант } \\
\text {-щ- }\end{array}$ & $\begin{array}{l}\text { Форми с импера- } \\
\text { тивен формант }\end{array}$ \\
\hline $\begin{array}{l}- \text { '-Ø-а } \\
\text { [постел'- } \\
\varnothing \text {-а] } \\
\text { постел- } \\
\varnothing \text {-я }\end{array}$ & $\begin{array}{l}\text {-е-Ø } \\
\text { постѐл- } \\
\text { e-Ø }\end{array}$ & $\begin{array}{l}-\mathrm{e}-\mathrm{M} \\
\text { постѐл- } \\
\text { e-м }\end{array}$ & $\begin{array}{l}\text {-а-х- } \varnothing \\
И \\
-и-\mathrm{-}-\varnothing \\
\text { постл-а-х- } \varnothing \\
И \\
\text { постел-и-х- } \varnothing\end{array}$ & \begin{tabular}{|l}
-е-х- $\emptyset$ \\
постѐл-е- \\
$x-\emptyset$
\end{tabular} & $\begin{array}{l}\text {-е-ш-е } \\
\text { потѐл-е- } \\
\text { ш-е }\end{array}$ & $\begin{array}{l}\text {-а-л- } \varnothing \\
\text { И } \\
\text {-и-л- } \\
\text { постл-а -л- } \\
\text { И } \\
\text { постел-и-л- }\end{array}$ & $\begin{array}{l}\text {-е-л-Ø } \\
\text { постѐл-е-л-Ø }\end{array}$ & $\begin{array}{l}\text {-е-л-и } \\
\text { постѐл-е-л-и }\end{array}$ & $\begin{array}{l}-\mathrm{a}-\mathrm{H}-\varnothing \\
И \\
-\mathrm{e}-\mathrm{-}-\varnothing \\
\text { постл-а -н- } \varnothing \\
И \\
\text { постел-е-н-Ø }\end{array}$ & - & $\begin{array}{l}\text {-Ø-ѝ-Ø, } \\
\text {-Ø-ѐ-те } \\
\text { постел-Ø-ѝ- } \varnothing \\
\text { постел-Ø-ѐ-те }\end{array}$ \\
\hline
\end{tabular}


ТИП 31 - обособява се от ТИП 30 въз основа на липса на форма със стойност на форманта -н-/-m-: СТЕЛЯ СЕ

\begin{tabular}{|c|c|c|c|c|c|c|c|c|c|c|c|c|}
\hline & $\begin{array}{l}\text { 1. л. ед. } \\
\text { ч. сег. вр. }\end{array}$ & $\begin{array}{l}\text { 3. л. ед. ч. } \\
\text { сег. вр. }\end{array}$ & $\begin{array}{l}\text { 1. л. мн.ч. } \\
\text { сег. вр. }\end{array}$ & $\begin{array}{l}1 \text { л. ед. ч. мин. } \\
\text { св. време }\end{array}$ & $\begin{array}{l}1 \text { л. ед. ч. } \\
\text { мин. несв. } \\
\text { време }\end{array}$ & $\begin{array}{l}3 \text { л. ед. ч. } \\
\text { мин. несв. } \\
\text { време }\end{array}$ & $\begin{array}{l}\text { М. р. ед. ч. } \\
\text { с формант -л- от } \\
\text { аористна основа }\end{array}$ & $\begin{array}{l}\text { М. р. ед. ч. с фор- } \\
\text { мант -л- от импер- } \\
\text { фектна основа }\end{array}$ & $\begin{array}{l}\text { Мн. ч. с формант } \\
\text {-л- от имперфек- } \\
\text { тна основа }\end{array}$ & $\begin{array}{l}\text { М. р. ед. ч. } \\
\text { с формант } \\
\text {-н/-т- }\end{array}$ & $\begin{array}{l}\text { М. р. ед. ч. } \\
\text { с формант } \\
\text {-щ- }\end{array}$ & $\begin{array}{l}\text { Форми с импера- } \\
\text { тивен формант }\end{array}$ \\
\hline 25 & $\begin{array}{l}\therefore-\varnothing-\mathrm{a} \\
\text { [стел'-Ø-а] } \\
\text { стел-Ø-я се }\end{array}$ & $\begin{array}{l}\text {-e-Ø } \\
\text { стѐл-е-Ø } \\
\text { се }\end{array}$ & $\begin{array}{l}\text {-е-м } \\
\text { стѐл-е-м } \\
\text { се }\end{array}$ & $\begin{array}{l}-\mathrm{a}-\mathrm{x}-\varnothing \\
И \\
\text {-и-х- } \varnothing \\
\text { стл-а-х- } \varnothing \text { се } \\
И \\
\text { стел-и-х- } \varnothing \text { се }\end{array}$ & $\begin{array}{l}-e-x-\varnothing \\
\text { стѐл-е- } \\
x-\emptyset \text { се }\end{array}$ & $\begin{array}{l}\text {-е-ш-е } \\
\text { стѐл-е- } \\
\text { ш-е се }\end{array}$ & $\begin{array}{l}-а-л-\varnothing \\
И \\
-и-л-\varnothing \\
\text { стл-а -л- Øсе } \\
И \\
\text { стел-и-л- Øсе }\end{array}$ & $\begin{array}{l}\text {-е-л- } \varnothing \\
\text { стѐл-е-л- } \varnothing \text { се }\end{array}$ & $\begin{array}{l}\text {-е-л-и } \\
\text { стѐл-е-л-и се }\end{array}$ & - & $\begin{array}{l}\text {-е-щ- } \varnothing \\
\text { стел-е-щ- } \varnothing \\
\text { се }\end{array}$ & 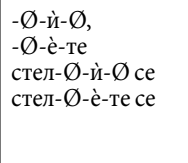 \\
\hline
\end{tabular}

ТИП 32 - обособява се от ТИП 2 въз основа на удължаване с интервокално [й] на словообразувателната основа, която завършва на гласна, във формите за 1 л. ед. и 3 л. мн. ч. сег. вр., където липсва тематична темпорална гласна, както и във формите, образувани от аористна основа (графично $я$ ); форми с императивен

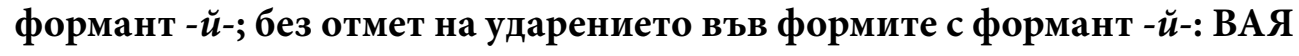

\begin{tabular}{|c|c|c|c|c|c|c|c|c|c|c|c|}
\hline $\begin{array}{l}\text { 1. л. ед. } \\
\text { ч. сег. вр. }\end{array}$ & $\begin{array}{l}\text { 3. л. ед. ч. } \\
\text { сег. вр. }\end{array}$ & $\begin{array}{l}\text { 1. л. мн.ч. } \\
\text { сег. вр. }\end{array}$ & $\begin{array}{l}1 \text { л. ед. ч. } \\
\text { мин. св. } \\
\text { време }\end{array}$ & $\begin{array}{l}1 \text { л. ед. ч. } \\
\text { мин. несв. } \\
\text { време }\end{array}$ & $\begin{array}{l}3 \text { л. ед. ч. } \\
\text { мин. несв. } \\
\text { време }\end{array}$ & $\begin{array}{l}\text { М. р. ед. ч. } \\
\text { с формант -л- от } \\
\text { аористна основа }\end{array}$ & $\begin{array}{l}\text { М. р. ед. ч. с фор- } \\
\text { мант -л- от импер- } \\
\text { фектна основа }\end{array}$ & $\begin{array}{l}\text { Мн. ч. с формант } \\
\text {-л- от имперфек- } \\
\text { тна основа }\end{array}$ & $\begin{array}{l}\text { М. р. ед. ч. } \\
\text { с формант } \\
\text {-н/-т- }\end{array}$ & $\begin{array}{l}\text { М. р. ед. ч. } \\
\text { с формант } \\
\text {-щ- }\end{array}$ & $\begin{array}{l}\text { Форми с импера- } \\
\text { тивен формант }\end{array}$ \\
\hline $\begin{array}{l}\text {-й-Ø-а (гра- } \\
\text { фично я) } \\
\text { [ва-й-Ø-а] } \\
\text { ва-Ø-я }\end{array}$ & $\begin{array}{l}\text {-е-Ø } \\
\text { ва-e- } \varnothing\end{array}$ & $\begin{array}{l}-е-м \\
\text { ва-е-м }\end{array}$ & $\begin{array}{l}\text {-й-a-х-Ø } \\
{[\text { ва-й-а-х-Ø] }} \\
\text { ва-я-х-Ø }\end{array}$ & $\begin{array}{l}\text {-e-x- } \varnothing \\
\text { ва-е-x- } \varnothing\end{array}$ & $\begin{array}{l}\text {-е-ш-е } \\
\text { ва-е-ш-е }\end{array}$ & $\begin{array}{l}\text {-й-а-л-Ø [в-а-й- } \\
\text { а-л-Ø] } \\
\text { ва-я-л-Ø }\end{array}$ & $\begin{array}{l}\text {-е-л- } \varnothing \\
\text { ва-е-л- } \varnothing\end{array}$ & $\begin{array}{l}\text {-е-л-и } \\
\text { ва-е-л-и }\end{array}$ & $\begin{array}{l}\text { [ва-й-а- } \\
\text { н-Ø] } \\
\text { ва-я-н-Ø }\end{array}$ & $\begin{array}{l}\text {-е-щ- } \\
\text { ва-е-щ- }\end{array}$ & $\begin{array}{l}\text { - } \text {-Й- } \varnothing, \\
\text {-Ø-й-те } \\
\text { ва̀-Ø-й-Ø } \\
\text { ва̀-Ø-й-те }\end{array}$ \\
\hline
\end{tabular}


ТИП 33 - обособява се от ТИП 32 въз основа на липса на форми с формант -щ-: ИЗВАЯ

\begin{tabular}{|c|c|c|c|c|c|c|c|c|c|c|c|}
\hline $\begin{array}{l}\text { 1. л. ед. } \\
\text { ч. сег. вр. }\end{array}$ & $\begin{array}{l}\text { 3. л. ед. ч. } \\
\text { сег. вр. }\end{array}$ & $\begin{array}{l}\text { 1. л. мн.ч. } \\
\text { сег. вр. }\end{array}$ & $\begin{array}{l}1 \text { л. ед. ч. } \\
\text { мин. св. } \\
\text { време }\end{array}$ & $\begin{array}{l}1 \text { л. ед. ч. } \\
\text { мин. несв. } \\
\text { време }\end{array}$ & $\begin{array}{l}3 \text { л. ед. ч. } \\
\text { мин. несв. } \\
\text { време }\end{array}$ & $\begin{array}{l}\text { М. р. ед. ч. } \\
\text { с формант -л- от } \\
\text { аористна основа }\end{array}$ & $\begin{array}{l}\text { М. р. ед. ч. с фор- } \\
\text { мант -л- от импер- } \\
\text { фектна основа }\end{array}$ & $\begin{array}{l}\text { Мн. ч. с формант } \\
\text {-л- от имперфек- } \\
\text { тна основа }\end{array}$ & $\begin{array}{l}\text { М. р. ед. ч. } \\
\text { с формант } \\
\text {-н/-т- }\end{array}$ & $\begin{array}{l}\text { М. р. ед. ч. } \\
\text { с формант } \\
\text {-щ- }\end{array}$ & $\begin{array}{l}\text { Форми } \\
\text { с императивен } \\
\text { формант }\end{array}$ \\
\hline $\begin{array}{l}\text {-й-Ø-а } \\
\text { [изва-й- } \\
\emptyset \text {-а] } \\
\text { изва-Ø-я }\end{array}$ & $\begin{array}{l}\text {-е- } \varnothing \\
\text { изва-е- } \varnothing\end{array}$ & $\begin{array}{l}\text {-е-м } \\
\text { изва-е-м }\end{array}$ & $\begin{array}{l}\text {-й-а-х-Ø } \\
\text { [изва-й-а- } \\
\text { х-Ø] } \\
\text { изва-я-х-Ø }\end{array}$ & $\begin{array}{l}\text {-е-х- } \varnothing \\
\text { изва-е-х- }\end{array}$ & $\begin{array}{l}\text {-е-ш-е } \\
\text { изва-е-ш-е }\end{array}$ & $\begin{array}{l}\text {-й-а-л- } \text { [изв-а-й- } \\
\text { а-л-Ø] } \\
\text { изва-я-л- }\end{array}$ & $\begin{array}{l}\text {-е-л-Ø } \\
\text { изва-е-л- Ø }\end{array}$ & $\begin{array}{l}\text {-е-л-и } \\
\text { изва-е-л-и }\end{array}$ & $\begin{array}{l}\text { [изва-й-а- } \\
\text { н-Ø] } \\
\text { изва-я-н-Ø }\end{array}$ & - & $\begin{array}{l}\text {-Ø-й-Ø, } \\
\text {-Ø-й-те } \\
\text { изва̀-Ø-й-Ø } \\
\text { изва̀-Ø-й-те }\end{array}$ \\
\hline
\end{tabular}

ТИП 34 - обособява се от ТИП 32 въз основа на липса на форми с формант -н-/-m-: БАЯ

\begin{tabular}{|c|c|c|c|c|c|c|c|c|c|c|c|}
\hline $\begin{array}{l}\text { 1. л. ед. } \\
\text { ч. сег. вр. }\end{array}$ & $\begin{array}{l}\text { 3. л. ед. ч. } \\
\text { сег. вр. }\end{array}$ & $\begin{array}{l}\text { 1. л. мн.ч. } \\
\text { сег. вр. }\end{array}$ & $\begin{array}{l}1 \text { л. ед. ч. } \\
\text { мин. св. } \\
\text { време }\end{array}$ & $\begin{array}{l}1 \text { л. ед. ч. } \\
\text { мин. несв. } \\
\text { време }\end{array}$ & $\begin{array}{l}3 \text { л. ед. ч. } \\
\text { мин. несв. } \\
\text { време }\end{array}$ & $\begin{array}{l}\text { М. р. ед. ч. } \\
\text { с формант -л- от } \\
\text { аористна основа }\end{array}$ & $\begin{array}{l}\text { М. р. ед. ч. с фор- } \\
\text { мант -л- от импер- } \\
\text { фектна основа }\end{array}$ & $\begin{array}{l}\text { Мн. ч. с формант } \\
\text {-л- от имперфек- } \\
\text { тна основа }\end{array}$ & $\begin{array}{l}\text { М. p. ед. ч. } \\
\text { с формант } \\
\text {-н/-т- }\end{array}$ & $\begin{array}{l}\text { М. р. ед. ч. } \\
\text { с формант } \\
\text {-щ- }\end{array}$ & $\begin{array}{l}\text { Форми с импера- } \\
\text { тивен формант }\end{array}$ \\
\hline 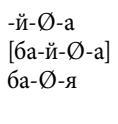 & $\begin{array}{l}-\mathrm{e}-\varnothing \\
б \mathrm{a}-\mathrm{e}-\varnothing\end{array}$ & $\begin{array}{l}-e-м \\
\text { ба-e-м }\end{array}$ & $\begin{array}{l}\text {-й-а-х- } \varnothing \\
\text { [ба-й-а- } \\
\text { x- } \varnothing] \\
\text { ба-я-х- } \varnothing\end{array}$ & $\begin{array}{l}\text {-e-x- } \varnothing \\
\text { ба-e-x- } \varnothing\end{array}$ & $\begin{array}{l}\text {-е-ш-е } \\
\text { ба-е-ш-е }\end{array}$ & $\begin{array}{l}\text {-й-а-л-Ø [6-а-й- } \\
\text { л-Ø] } \\
\text { ба-я-л-Ø }\end{array}$ & $\begin{array}{l}\text {-е-л- } \varnothing \\
\text { ба-е-л- } \varnothing\end{array}$ & $\begin{array}{l}\text {-е-л-и } \\
\text { ба-е-л-и }\end{array}$ & - & $\begin{array}{l}\text {-е-щ- } \varnothing \\
\text { ба-е-щ-Ø }\end{array}$ & 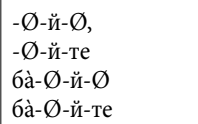 \\
\hline
\end{tabular}

ТИП 35 - обособява се от ТИП 34 въз основа на липса на форми с формант -щ-: ПОБАЯ

\begin{tabular}{|c|c|c|c|c|c|c|c|c|c|c|c|}
\hline $\begin{array}{l}\text { 1. л. ед. } \\
\text { ч. сег. вр. }\end{array}$ & $\begin{array}{l}\text { 3. л. ед. ч. } \\
\text { сег. вр. }\end{array}$ & $\begin{array}{l}\text { 1. л. мн.ч. } \\
\text { сег. вр. }\end{array}$ & $\begin{array}{l}1 \text { л. ед. ч. } \\
\text { мин. св. } \\
\text { време }\end{array}$ & $\begin{array}{l}1 \text { л. ед. ч. } \\
\text { мин. несв. } \\
\text { време }\end{array}$ & $\begin{array}{l}3 \text { л. ед. ч. } \\
\text { мин. несв. } \\
\text { време }\end{array}$ & $\begin{array}{l}\text { М. р. ед. ч. } \\
\text { с формант -л- от } \\
\text { аористна основа }\end{array}$ & $\begin{array}{l}\text { М. р. ед. ч. с фор- } \\
\text { мант -л- от импер- } \\
\text { фектна основа }\end{array}$ & $\begin{array}{l}\text { Мн. ч. с формант } \\
\text {-л- от имперфек- } \\
\text { тна основа }\end{array}$ & $\begin{array}{l}\text { М. р. ед. ч. } \\
\text { с формант } \\
\text {-н/-т- }\end{array}$ & $\begin{array}{l}\text { М. р. ед. ч. } \\
\text { с формант } \\
\text {-щ- }\end{array}$ & $\begin{array}{l}\text { Форми с импера- } \\
\text { тивен формант }\end{array}$ \\
\hline $\begin{array}{l}\text {-й-Ø-а } \\
\text { [поба-й- } \\
\emptyset \text {-а] } \\
\text { поба-Ø-я }\end{array}$ & $\begin{array}{l}\text {-е-Ø } \\
\text { поба-е-Ø }\end{array}$ & $\begin{array}{l}\text {-е-м } \\
\text { поба-е-м }\end{array}$ & $\begin{array}{l}\text {-й-а-х-Ø } \\
\text { [поба-й-а- } \\
\text { х-Ø] } \\
\text { поба-я-х-Ø }\end{array}$ & $\begin{array}{l}\text {-е-x- } \varnothing \\
\text { поба-е- } \\
x-\varnothing\end{array}$ & $\begin{array}{l}\text {-е-ш-е } \\
\text { поба-е- } \\
\text { ш-е }\end{array}$ & $\begin{array}{l}\text {-й-а-л-Ø [поб-а- } \\
\text { й-л-Ø] } \\
\text { поба-я-л-Ø }\end{array}$ & $\begin{array}{l}\text {-е-л- } ~ \\
\text { поба-е-л- } \varnothing\end{array}$ & $\begin{array}{l}\text {-е-л-и } \\
\text { поба-е-л-и }\end{array}$ & - & - & $\begin{array}{l}\text { - } \text {-й- } \varnothing, \\
\text { - } \text {-й-те } \\
\text { поба̀- } \varnothing \text {-й-Ø } \\
\text { поба̀- Ø-й-те }\end{array}$ \\
\hline
\end{tabular}


ТИП 36 - обособява се от ТИП 32 поради липса на форми за аорист и на форми, образувани от аористна основа: УХАЯ

(Забележка: от тези глаголи няма производни глаголи, които биха ни дали сведения за аористната основа, както е напр. глаголът ида с производен отида, от който личи, че аористна основа е на -о-: -отидох. Затова само условно и по сведения за форма на аорист от по-стари периоди ги причисляваме към КЛАС 1 . Те биха могли да се причислят и към КЛАС 5. КОМБИНАТОРИКА -Е-Ø/-Ø-Х/-Е-Х-Ø.)

\begin{tabular}{|c|c|c|c|c|c|c|c|c|c|c|c|}
\hline $\begin{array}{l}\text { 1. л. ед. } \\
\text { ч. сег. вр. }\end{array}$ & $\begin{array}{l}\text { 3. л. ед. ч. } \\
\text { сег. вр. }\end{array}$ & $\begin{array}{l}\text { 1. л. мн.ч. } \\
\text { сег. вр. }\end{array}$ & $\begin{array}{l}1 \text { л. ед. ч. } \\
\text { мин. св. } \\
\text { време }\end{array}$ & $\begin{array}{l}1 \text { л. ед. ч. } \\
\text { мин. несв. } \\
\text { време }\end{array}$ & $\begin{array}{l}3 \text { л. ед. ч. } \\
\text { мин. несв. } \\
\text { време }\end{array}$ & $\begin{array}{l}\text { М. р. ед. ч. } \\
\text { с формант -л- от } \\
\text { аористна основа }\end{array}$ & $\begin{array}{l}\text { М. р. ед. ч. с фор- } \\
\text { мант -л- от импер- } \\
\text { фектна основа }\end{array}$ & $\begin{array}{l}\text { Мн. ч. с формант } \\
\text {-л- от имперфек- } \\
\text { тна основа }\end{array}$ & $\begin{array}{l}\text { М. р. ед. ч. } \\
\text { с формант } \\
\text {-н/-т- }\end{array}$ & $\begin{array}{l}\text { М. р. ед. ч. } \\
\text { с формант } \\
\text {-щ- }\end{array}$ & $\begin{array}{l}\text { Форми с импера- } \\
\text { тивен формант }\end{array}$ \\
\hline $\begin{array}{l}\text {-й-Ø-а } \\
\text { [уха-й- } \\
\emptyset \text {-а] } \\
\text { уха-Ø-я }\end{array}$ & $\begin{array}{l}\text {-e- } \varnothing \\
\text { yхa-e- } \varnothing\end{array}$ & $\begin{array}{l}-e-м \\
\text { yха-e-м }\end{array}$ & - & $\begin{array}{l}\text {-e-x- } \varnothing \\
\text { yxa-e-x- } \varnothing\end{array}$ & $\begin{array}{l}\text {-е-ш-е } \\
\text { уха-е-ш-е }\end{array}$ & - & $\begin{array}{l}\text {-е-л- } \varnothing \\
\text { уха-е-л- } \varnothing\end{array}$ & $\begin{array}{l}\text {-е-л-и } \\
\text { уха-е-л-и }\end{array}$ & - & $\begin{array}{l}\text {-е-щ- } \varnothing \\
\text { уха-е-щ-Ø }\end{array}$ & $\begin{array}{l}\text {-Ø-й- } \varnothing, \\
\text {-Ø-й-те } \\
\text { уха̀- } \varnothing \text {-й- } \varnothing \\
\text { уха̀- } \varnothing \text {-й-те }\end{array}$ \\
\hline
\end{tabular}

ТИП 37 - обособява се от ТИП 36 поради дублетност в основната форма (едноелементно множество): ЗНАЯ и ЗНАМ

\begin{tabular}{|c|c|c|c|c|c|c|c|c|c|c|c|}
\hline $\begin{array}{l}\text { 1. л. ед. } \\
\text { ч. сег. вр. }\end{array}$ & $\begin{array}{l}\text { 3. л. ед. } \\
\text { ч. сег. } \\
\text { вр. }\end{array}$ & $\begin{array}{l}\text { 1. л. } \\
\text { мн.ч. } \\
\text { сег. вр. }\end{array}$ & $\begin{array}{l}1 \text { л. ед. ч. } \\
\text { мин. св. } \\
\text { време }\end{array}$ & $\begin{array}{l}1 \text { л. ед. ч. } \\
\text { мин. несв. } \\
\text { време }\end{array}$ & $\begin{array}{l}3 \text { л. ед. ч. } \\
\text { мин. несв. } \\
\text { време }\end{array}$ & $\begin{array}{l}\text { М. р. ед. ч. } \\
\text { с формант -л- от } \\
\text { аористна основа }\end{array}$ & $\begin{array}{l}\text { М. р. ед. ч. с фор- } \\
\text { мант -л- от импер- } \\
\text { фектна основа }\end{array}$ & $\begin{array}{l}\text { Мн. ч. с формант } \\
\text {-л- от имперфек- } \\
\text { тна основа }\end{array}$ & $\begin{array}{l}\text { М. р. ед. ч. } \\
\text { с формант } \\
\text {-н/-т- }\end{array}$ & $\begin{array}{l}\text { М. р. ед. ч. } \\
\text { с формант } \\
\text {-щ- }\end{array}$ & $\begin{array}{l}\text { Форми с импера- } \\
\text { тивен формант }\end{array}$ \\
\hline $\begin{array}{l}\text {-й-Ø-а } \\
\text { [зна-й-Ø-а И зна-Ø-м] } \\
\text { зна-Ø-я И } \\
\text { зна-Ø-м }\end{array}$ & $\begin{array}{l}\text {-е- } \varnothing \\
\text { зна-е- } \varnothing\end{array}$ & $\begin{array}{l}\text {-е-м } \\
\text { зна-е-м }\end{array}$ & - & $\begin{array}{l}-е-x-\varnothing \\
\text { зна-е-х-Ø }\end{array}$ & $\begin{array}{l}\text {-е-ш-е } \\
\text { зна-е-ш-е }\end{array}$ & - & $\begin{array}{l}\text {-е-л- } \varnothing \\
\text { зна-е-л- } \varnothing\end{array}$ & $\begin{array}{l}\text {-е-л-и } \\
\text { зна-е-л-и }\end{array}$ & - & $\begin{array}{l}\text {-е-щ-Ø } \\
\text { зна-е-щ-Ø }\end{array}$ & $\begin{array}{l}\text {-Ø-й- }, \\
\text {-Ø-й-те } \\
\text { 3на̀-Ø-й-Ø } \\
\text { 3на̀-Ø-й-те }\end{array}$ \\
\hline
\end{tabular}




\section{БИБЛИОГРАФИЯ}

Vachek, J. (2014). Remarks on the dynamism of the system of language. In J. Chovanec, Chapters from the history of Czech functional linguistics (pp. 54-63). Brno: Masarykova univerzita.

Граматика на съвременния български книжовен език: Морфология (Vol. 2) [ГСБКЕ]. (1983). София: Издателство на БАН.

Кръстев, Б. (1997). Морфологията на българския език в 187 типови таблици (3rd ed.). София: Наука и изкуство.

Куцаров, И. (2007). Теоретична граматика на българския език: Морфология. Пловдив: УИ „Паисий Хилендарски“.

Малджиева, В. (2009). Български език. In П. Пипера (Еd.), Јужнословенски језици: Граматичке структуре и функције (рр. 19-141). Београд: Београдска књига.

Ницолова, Р. (2008). Българска граматика: Морфология. София: Университетско издателство „Св. Климент Охридски“.

Официален правописен речник на българския език [ОПР]. (2012). София: Просвета.

Официален правописен речник на българския език: Глаголи [ОПРГ]. (2016). София: Просвета.

Пашов, П. (1966). Българският глагол. София: Наука и изкуство.

Пашов, П. (1976). За основите при глаголното формообразуване в съвременния български книжовен език. In П. Пашов \& Р. Ницолова, Помагало по българска морфология: Глагол (рр. 48-59). София: Наука и изкуство.

Плунгян, В. А. (1998). Проблемы грамматического значения в современных морфологических теориях (обзор). Семиотика и информатика, 36, 324-386.

Попов, Д., Симов, К., \& Видинска, С. (Еds.). (1998). Речник за правоговор, правопис, пунктуация [РППП]. София: Атлантис КЛ.

Станчева, Р. (2018). Принципи на изследването на формалните класове при глаголните лексеми в съвременния български книжовен език. Slavia Meridionalis, 18. https://doi.org/10.11649/sm.1676

Теодоров-Балан, А. (1940). Нова българска граматика. София: Книгоиздателство Т. Ф. Чипев.

Томова, К., \& Карастанева, Ц. (1984). Спрежение на българските глаголи. Пловдив: ВМИ „Ив. П. Павлов“.

Тополинска, 3. (2009). Македонски јазик. In П. Пипера (Еd.), Јужнословенски језици: Граматичке структуре и функције (рр. 141-253). Београд: Београдска књига. 


\section{BIBLIOGRAPHY}

\section{(TRANSLITERATION)}

Gramatika na sŭvremenniia bŭlgarski knizhoven ezik: Morfologiia (Vol. 2) [GSBKE]. (1983). Sofiia: Izdatelstvo na BAN.

Krŭstev, B. (1997). Morfologiiata na bŭlgarskiia ezikv 187 tipovi tablitsi (3rd ed.). Sofiia: Nauka i izkustvo.

Kutsarov, I. (2007). Teoretichna gramatika na bŭlgarskiia ezik: Morfologiia. Plovdiv: UI "Paisiŭ Khilendarski”.

Maldzhieva, V. (2009). Bŭlgarski ezik. In P. Pipera (Ed.), Južnoslovenski jezici: Gramatičke strukture i funkcije (pp. 19-141). Beograd: Beogradska knjiga. Nitsolova, R. (2008). Bŭlgarska gramatika: Morfologiia. Sofiia: Universitetsko izdatelstvo “Sv. Kliment Okhridski”.

Ofitsialen pravopisen rechnik na bŭlgarskiia ezik [OPR]. (2012). Sofiia: Prosveta.

Ofitsialen pravopisen rechnik na bŭlgarskiia ezik: Glagoli. [OPRG]. (2016). Sofiia: Prosveta.

Pashov, P. (1966). Bŭlgarskiiat glagol. Sofiia: Nauka i izkustvo.

Pashov, P. (1976). Za osnovite pri glagolnoto formoobrazuvane v sŭvremenniia bŭlgarski knizhoven ezik. In P. Pashov \& R. Nitsolova, Pomagalo po bŭlgarska morfologiia: Glagol (pp. 48-59). Sofiia: Nauka i izkustvo.

Plungian, V. A. (1998). Problemy grammaticheskogo znacheniia v sovremennykh morfologicheskikh teoriiakh (obzor). Semiotika i informatika, $36,324-386$.

Popov, D., Simov, K., \& Vidinska, S. (Eds.). (1998). Rechnik za pravogovor, pravopis, punktuatsiia [RPPP]. Sofiia: Atlantis KL.

Stancheva, R. (2018). Printsipi na izsledvaneto na formalnite klasove pri glagolnite leksemi v sŭvremenniia bŭlgarski knizhoven ezik. Slavia Meridionalis, 18. https://doi.org/10.11649/sm.1676

Teodorov-Balan, A. (1940). Nova bŭlgarska gramatika. Sofiia: Knigoizdatelstvo T. F. Chipev.

Tomova, K., \& Karastaneva, T. (1984). Sprezhenie na bŭlgarskite glagoli. Plovdiv: VMI "Iv. P. Pavlov".

Topolińska, Z. (2009). Makedonski jezik. In P. Piper (Ed.), Južnoslovenski jezici: gramatičke strukture i funkcije (pp. 141-253). Beograd: Beogradska knjiga.

Vachek, J. (2014). Remarks on the dynamism of the system of language. In J. Chovanec, Chapters from the history of Czech functional linguistics (pp. 54-63). Brno: Masarykova univerzita. 


\section{Typy fleksyjne w ramach pierwszej koniugacji w literackim języku bułgarskim}

W artykule przedstawiono propozycję zmodyfikowania klasyfikacji niektórych czasowników pierwszej koniugacji w języku bułgarskim w oparciu o pewien zestaw cech klasyfikacyjnych i form diagnostycznych. Procedura, według której bułgarskie czasowniki jednej z dziewięciu klas formalnych podzielone zostają na typy fleksyjne, składa się z trzech poziomów kategoryzacji: 1) według kryterium morfologicznego, 2) według rodzajów zmian morfologicznych (regresywnych) zakodowanych w formach słowotwórczych lub gramatycznych, 3) według kryterium normatywnego (obecność dubletów). Uwzględniana jest również kombinatoryka morfów w zbiorze form czasownika. Prezentacja cech formalnych odbywa się w gramatyce normatywnej przy uwzględnieniu dynamiki normy. Model ma na celu opracowanie wszystkich czasowników bułgarskich poprzez kombinację różnych kryteriów leksykalno-gramatycznych klasyfikacji.

Słowa kluczowe: bułgarskie czasowniki, struktura formalna, formy fleksyjne bułgarskich czasowników, cechy formalne, kryteria klasyfikacji, gramatyka normatywna

\section{Inflectional Types within First Conjugation in Standard Bulgarian}

The article presents the modulation models in some first conjugation verbs in the Bulgarian language based on a certain set of classification characteristics and diagnostic forms. The inflection types within one of the nine classes in which the Bulgarian verbal vocabulary are distinguished according to a procedure which comprises three levels of categorization: 1) by a morphological criterion; 2) by types of morphological (regressive) changes encoded in word-forming or grammatical forms, and 3) by a normative criterion (presence of doublets). Also considered is the combinatorics of the grammatical morphs in the set of verb forms. The presentation of formal types is done in terms of normative grammar, taking into account the dynamism of the norm. The model aims to cover the entire verbal vocabulary by uniting different lexical-grammatical classifications of the Bulgarian verbs.

Keywords: Bulgarian verbs, formal structure, inflection types in Bulgarian verbs, formal features, classification criteria, normative grammar 


\section{Notki o autorkach}

Tatyana Aleksandrova (Татяна Александрова) (t_alexandrova_@mail.bg) - specjalistka w obszarze bułgarskiej filologii, zwłaszcza języka; docent doktor w Instytucie Języka Bułgarskiego im. Prof. Ljubomira Andrejczina Bułgarskiej Akademii Nauk (2007-2018). Autorka opracowań: Повърхнинни реализации на логическата функиия $Р(р, y)$ в българския език (2006); Българският книжовен език като националноидентификационен проект през Възраждането (2008); Семантика на минали страдателни причастия от непреходни глаголи (2009); Деепричастието - кодифицирана норма и актуална езикова практика (2016); Официален правописен речник на българския език (współautor; 2012); Обициален правописен речник на българския език. Глаголи (współautor; 2016). Zainteresowania badawcze: historia i teoria języka standardowego, gramatyka języka bułgarskiego, kultura języka, norma i kodyfikacja.

Tatyana Aleksandrova (t_alexandrova_@mail.bg) - PhD in Bulgarian Philology, linguist; Associate Professor at the Prof. Lyubomir Andreychin Institute of Bulgarian Language, Bulgarian Academy of Sciences (2007-2018). Author of the studies: Повърхнинни реализации на логическата функиия $P(p, y)$ в българския език [Surface realizations of the logical function P(p,y) in the Bulgarian language] (2006); Българският книжовен език като националноидентификационен проект през Възраждането [The Bulgarian literary language as a project national identity building during the Bulgarian National Revival] (2008); Семантика на минали страдателни причастия от непреходни глаголи [Sетапtics of past passive participles of intransitive verbs] (2009); Деепричастието - кодифицирана норма и актуална езикова практика [The adverbial articiple - codified norm and actual language practice] (2016); Официален правописен речник на българския език [Official spelling dictionary of the Bulgarian language] (co-author, 2012); Официален правописен речник на българския език. Глаголи [Official spelling dictionary of the Bulgarian language. Verbs] (co-author, 2016). Research interests: history and theory of standard language; Bulgarian language grammar; language culture; norm and codification. 
Ruska Stancheva (Руска Станчева) (rustancheva@gmail.com) - slawistka, specjalistka w zakresie języka polskiego i bułgarskiego; docent w Zakładzie Współczesnego Języka Bułgarskiego Instytutu Języka Bułgarskiego BAN; wykładowca kultury języka w NBU (1996-2013). Autorka publikacji: Теоретична рамка на изследването на обществените нагласи кбм съвременния български книжовен език като фактор при кодификаиията на нормите му (2017), Категорията време на глагола в пьрвите научни граматики на българския език (с оглед на значенията на сегашно време) (2016), За т. нар. "двувидови” глаголи в българския език (2009). Współautor: Официален правописен речник на българския език. Глаголи (2016), Официален правописен речник на българския език (2012). Zainteresowania badawcze: norma i kodyfikacja języków literackich, gramatyka bułgarska, postawy językowe.

Ruska Stancheva (rustancheva@gmail.com) - Slavist, specializing in the Polish and Bulgarian languages; Associate Professor at the Institute for Bulgarian Language, Bulgarian Academy of Sciences, lecturer in language culture at the New Bulgarian University (1996-2013). Main publications: За т. нар. “двувидови” глаголи в бвлгарския език [On so-called "two-aspect" verbs in Bulgarian] (2009), Категорията време на глагола в първите научни граматики на българския език (с оглед на значенията на сегашно време) [On the category of verb tense in earliest scientific grammars of Bulgarian (with regard to the meanings of the present tense)] (2016), Теоретична рамка на изследването на обществените нагласи към съвременния български книжовен език като фактор при кодификацията на нормите му [A theoretical framework for the study of public attitudes towards contemporary Bulgarian literary language as a factor in the codification of its norms] (2017). Co-authored: Официален правописен речник на българския език [Official spelling dictionary of the Bulgarian language] (2012), Официален правописен речник на българския език. Глаголи [Official spelling dictionary of the Bulgarian language. Verbs] (2016). Research interests: standard language - norm and codification; Bulgarian grammar (descriptive and prescriptive), language attitudes. 